\title{
The Twilight of Reason: Neo-Conservatism and Corruption at Adelphi University, 1985-1997
}

\section{Daniel Rosenberg ${ }^{1}$}

During the administration of President Peter Diamandopoulos (1985-1997), Adelphi University elicited considerable national attention. When faculty opposition to Diamandopoulos prompted the New York State Board of Regents to investigate reports of trustee and presidential malfeasance, the peculiar circumstances at the Long Island institution became unprecedented matters of public scrutiny, drawing reporters from national, as well as local, media, and from publications dealing with higher education. Evidence before the Regents indicated exorbitant self-aggrandizement, extensive violations of non-profit and board procedures, and of ethical norms in education, leading the state body to remove the trustees in early $1997 .^{2}$

While the Regents' hearings and concurrent reporting publicly revealed the mercurial personality of Diamandopoulos, the coverage tended to obscure political factors, which facilitated and rationalized the operations of the president and his associates among the trustees. The following article will present an analysis of these dimensions in particular, giving relevant attention to, while leaving aside a fuller exposition of, the removal process.

The president was a political animal, and not only in the customary sense of campus maneuvering, but one with clearly right-wing proclivities, notwithstanding his stated pursuit of an expansive "liberal learning." Despite the evidence of malfeasance, he attracted support from important organizations, national leaders, editorial boards, and foundations opposed to multiculturalism, campus unions, and the values of the 1960s perceived to be embodied within. However possessed (as the Regents hearings showed) of an overripe selfesteem, he was never abstractly opportunistic, but steered consistently rightward. Diamandopoulos came to represent those who favored the approach to "liberal learning" based on the "core" principles and thinkers in the Western academy, with a Eurocentric emphasis in disciplines within the humanities and social sciences. He supported rigid hierarchy in academic life and administration, which he upheld as the standard modus operandi before Adelphi faculty. And, in the acquisitive ethos according to which he lived, and to which he testified before the Board of Regents, he proclaimed the justice of wealth accumulation, so often exalted (as Thorsten Veblen demonstrated so long ago) by the very privileged. ${ }^{3}$

Association with hard-line figures on the right gave Diamandopoulos a certain base, and a rationale to contend that his struggle with faculty and other opponents had nothing to do with the widely rumored and subsequently con- 
firmed improprieties. He could and did claim that the effort to unseat him and the board actually involved a recalcitrant faculty's prejudice against his tradition-rooted, but far-sighted, curricular reforms and steps to reduce union influence. Leading protagonists of Diamandopoulos' views delivered keynotes at commencement exercises: Robert Bork, the rejected Supreme Court nominee; Dick Cheney, the former Secretary of Defense and future vice-president; William F. Buckley, the editor of The National Review; and Conor Cruise O'Brien, the Irish nationalist whose views shifted right. Both Cheney (1992) and Buckley (1995) devoted their addresses to the need for continued vigilance against the threat of communism. ${ }^{4}$

Hence, Diamandopoulos could contend that he and the board were manning the barricades against empowered faculty liberalism, alongside those who were waging the national battle to restore the purity of higher education. But at Adelphi, the trend toward neo-conservatism, which featured the presence of emphatically rightwing ideologues, the hiring of faculty sponsored by neo-conservative thinktanks, the advent of similarly inclined figures in the administration, and the appointment of articulate theorists like William E. Simon and John Silber as Adelphi trustees, was accompanied by an ever-growing disregard for norms of the academy. Nor did Diamandopoulos' supporters fail to defend his conduct.

The literature on neo-conservatism suggests that its protagonists share a conviction that since the 1960 s a "New Class" has held sway in broad areas of American decision-making (including higher education), a group derived from "intellectuals, countercultural youth and black power militants," whose "egalitarian" influence (according to William E. Simon, whose affinity for the neoconservative ethos grew over the years) has been ironically abetted by cowed members of the business elite, as well as by other authorities. Other common principles, writes Peter Steinfels, include strident anti-communism, bitterly inspired in part by the former liberal and leftist affiliations of many adherents, trust in "the market" as the objective producer of social success (akin to the libertarian theories of Friedrich Hayek and Ayn Rand), and strong advocacy of the superiority of Western Civilization. ${ }^{5}$

It is common for adherents to claim that they support "liberal learning" and represent a purer liberalism, and to cite past support of civil rights and civil liberties to prove the point, as does John Silber. It is held that authentic liberalism, founded in a belief in genuine freedom, has in fact been thoroughly betrayed by today's leftists and purported liberals. The latter, it is believed, have "quite taken over the establishments of high culture, and most especially the universities." Indeed, neo-conscrvatives charge that modern academics commit the gravest offense by welcomvig the subjective curricular whims of feminists and black nationalists, restricting freedom of others to teach and think tra- 
ditionally. Ironically, neo-conservatives espousing freedom would deny a place in the academy for ethnic and women's studies. Gary Dorrien notes that in their prodigious efforts to build a host of magazines and organizations in resistance to the alleged status quo, neo-conservatives have tended to antagonize more traditional conservatives, who have resented the power-flexing, "intrigue," and enviable scale of organization and funding involved in neo-conservative policy aspirations. Nor do the journals of neo-conservatism, such as Hilton Kramer's New Criterion, open their pages freely to conservatives whose cultural outlook differs from their own. Despite the complaints of important "paleoconservatives," many of the newer variety had achieved prominence in the educational, defense, and foreign policy realms of the Reagan Administration by the time Peter Diamandopoulos became president of Adelphi. ${ }^{6}$

Former Treasury Secretary William E. Simon joined the Adelphi board of trustees in the fall of 1989, on the fourth anniversary of Diamandopoulos' assumption of the presidency. At virtually the same time, the board recruited Boston University president, John Silber. Their appointments came in the immediate aftermath of the first serious crisis under Diamandopoulos. ${ }^{7}$

During the previous winter, a bitter strike for union recognition had been conducted by clerical workers in Local 153 of the Office and Professional Employees International Union, who by all accounts were miserably paid. The president, reported the The Delphian, adopted an "aristocratic" attitude to the predominantly female strikers, viewing them "as housewives who shouldn't even be here." In a meeting with students, Diamandopoulos reflected nostalgically back to the days when secretaries took whatever jobs and pay were available, "and felt grateful to have their jobs. Five-eight-ten years later, when things seem a little better, they want a little bit of the action." The contention of the strike, and the sharp criticisms of his stance, gladdened him: "Nothing excites me more, flatters me more, nothing makes me prouder, than to create situations for arguments, discussions, debates, to the dialectic of this issuc rather than that issue." 8

Six weeks passed before the university recognized the union, to the regret of the reluctant president: "Now I have to find the money somewhere." He added: "I remain negative about strikes as an influence on collective bargaining." In the meantime, at a meeting chaired by Diamandopoulos, the faculty adopted a motion to dismiss the president: he walked out. In sending the motion to the Board of Trustees, the faculty declared "that there is an urgent and widespread management crisis at Adelphi University." The president and other officers had evidenced "a total lack of respect, and even contempt for all members of the university - students, faculty, and staff." The student government passed a similar resolution. In a preview of what was to come six years later, the board supported the president, and refused to meet with faculty representatives. 
Board member Hilton Kramer, the former New York Times cultural critic and a partisan of neo-conservative politics, stated: "No other response is called for." Two months after the faculty motion, the trustees reiterated "unequivocal support" for Diamandopoulos, emphasizing ultimate authority in warning professors to "cease and desist from further unsolicited representations to the board."

Emboldened by trustee support, Diamandopoulos began the Fall 1989 semester with the announcement of five administrative appointments, without faculty searches or approval. Historian Armstrong Starkey averred that the president had broken shared governance rules "in a massive and unprecedented way." The appointments stuck nevertheless. It was then that the Board of Trustees added William E. Simon and John Silber to its ranks. ${ }^{10}$

Silber, who resembled Diamandopoulos in style and approach, had dominated the president's inauguration ceremony, and was a known figure in higher education: his keynote address had attacked the "drift" consequent to the 1960 s, wherein "the authority of traditional cultural forms" had weakened, and "cherished beliefs about the nature of individuals, groups, and nations were abandoned." Among his accomplishments had been the decertification of the Boston University faculty union (a chapter of the American Association of University Professors), on the grounds that faculty could not have both managerial and adversarial relationships with university administration. The latter view, epitomized in the narrow 1980 Supreme Court majority decision in National Labor Relations Board v. Yeshiva University, would penetrate the relationship between Adelphi's faculty and trustees, for Diamandopoulos and trustee Silber became bitter exponents of the Court's opinion. (Unions at several private universities pressed forward nonetheless, for as Justice William Brennan pointed out in dissent, higher education had become as much a "big business" as "any large industrial organization," confronting faculty with "budgetary cutbacks, declining enrollments, reductions in faculty appointments, curtailment of academic programs" and other factors leading to "the erosion of the faculty's role in the institution's decision-making process." $)^{11}$

Simon's reputation had been made in a larger arena, with broader significance in government, policy-making, business, and Catholic institutions; hence his importance to the board would transcend that of any other member. Simon, who was awarded the university's "Integrity in American Leadership President's Award" amidst the tensions of the previous spring, had emerged during the administration of Richard Nixon as a leading figure in American energy and economic policy. ${ }^{12}$

His wealth at the moment of his appointment to Adelphi's Board of Trustees was assumed to be in the neighborhood of $\$ 300$ million. Simon was heavily involved in a number of banking ventures and in corporate mergers. An extraordinarily eloquent man, perhaps more so than the articulate Silber, Simon 
was fearless in presentation of his views and policies: an obituary used such phrases as "aggressive," "quick-tempered," "outspoken," and "thick-skinned" to describe him. In fact, he was the ideal choice to join the Adelphi board in the fall of $1989 .{ }^{13}$

Simon, whose "blunt style and willingness to talk publicly of his views" earned him the sobriquet "William the Terrible" in the Nixon and Ford administrations, became something of an evangelist for a notably uncritical way of seeing the free enterprise system during his association with Adelphi. To Simon, capitalism had imbued America "with the greatest prosperity, the highest standard of living, and, most important, the greatest individual freedom ever known to man." The ethics of free enterprise, he felt, were at the core of Western Civilization. The blunt Simon reserved his sharpest comment for business leaders who helped support liberal, environmental, and other groups which criticized certain or many aspects of capitalism. Such businessmen "long to be viewed as 'progressive' and 'socially responsible,' no matter to what asinine end this leads them. They are in mortal terror of being branded 'conservative' or 'rapacious' or 'insensitive' or 'exploiters,' and of losing seats at the annual dinners of organizations dedicated to their destruction." Instead, businessmen should never stop proclaiming the philosophy and ideal of free enterprise. $^{14}$

In much the same manner as John Silber, William E. Simon felt that "intellectual and moral bankruptcy" afflicted American higher education, "a wider sickness that is infecting institutions of higher learning across the country." Foremost among the symptoms were "hostility toward Western civilization, the contempt for donors and standards of honesty in dealing with them, [and the] practice of invoking the sacred cow of academic freedom as a cover for hypocrisy and irresponsibility." 15

Accordingly, Simon devoted a great measure of his work in the John M. Olin and William E. Simon Foundations to reversing the educational trend he disdained. The Olin Foundation, which he headed from 1977 until his death in 2000 , became a particularly active player on the college circuit, funding programs and professors (called Olin Scholars) in line with neo-conservative tastes. The Olin Foundation was by no means the only funding group of the hard right to emerge prominently in the 1980s: there were also the Scaife Family Foundations, the Bradley Foundations, the Coors Foundation, and the Smith Richardson Foundation, among others, sustaining and creating a broad network of thinktanks in their own right. Scaife funds, for example, poured into the Hoover Institution, the Reason Foundation, the American Enterprise Institute, the Heritage Foundation, the Cato Institute, the Foundation for Economic Education, the Manhattan Institute, and the National Association of Scholars. "(T)here came into being a network of conservative foundations that 
had no parallel in the liberal camp," sharing the mission of "promoting laissezfaire economic policies," notes a student of the phenomenon. But the Olin Foundation pinpointed the funding of university programs. ${ }^{16}$

The recipients of Olin funding during the years of Simon's stewardship read like a Who's Who of the nation's most influential neo-conservative protagonists and policy-shapers: Robert Bork (who was Olin Scholar in Legal Studies at the American Enterprise Institute when he addressed Adelphi commencement in 1990), Dinesh D'Souza, Abigail and Stephan Thernstrom, Allan Bloom, Irving Kristol, Samuel Huntington, and Charles Murray (The Bell Curve). Other beneficiaries, among hundreds, have included influential thinktanks, generally ultra-conservative: the Hudson Institute (from which Adelphi interim provost Mark Blitz emerged, toward the end of the Diamandopoulos period), the Manhattan Institute, the Heritage Foundation, the National Association of Scholars, the Cato Institute, the American Enterprise Institute, the Council on Foreign Relations, the National Right to Work Legal Defense Foundation, and the Historical Society. Crossbreeding between the Olin and Scaife foundations is evident. Another Olin recipient, the American Academy for Liberal Education, enunciates an essentially back-to-the classics standard (highlighted by Western Civilization) for college accreditation: its president, Jeffrey D. Wallin, was formerly Special Assistant to Diamandopoulos. Earlier, the Olin Foundation provided seed money to future Adelphi trustee Hilton Kramer for the New Criterion in 1982. ${ }^{17}$

Representatives of such groups wear many hats, interact in the normal course of promoting views and exchanging views, and crossed paths at diverse venues in the 1980s and 1990s, Adelphi included. The Manhattan Institute, for example, is a veritable neo-conservative intersection, providing its podium to Hilton Kramer, the Hoover Institution's Thomas Sowell, the Fordham Foundation's (and Olin Fellow) Chester Finn, Commentary's (and Hudson Institute Fellow) Norman Podhoretz, and the columnist (and Diamandopoulosera Adelphi speaker) Stanley Crouch, among others. ${ }^{18}$

William E. Simon began several lecture series, some under the direct aegis of the Olin Foundation, at dozens of campuses. Series were variously titled "Olin Lectures" or "William E. Simon Lectures," the latter with the occasional coda "in American Civilization and Values." Simon himself initiated the Olin/Simon lecture tradition at Adelphi by addressing the campus on the topic of Christopher Columbus in 1992. This was the first local manifestation of the national series in American Civilization and Values. Peter Diamandopoulos gave the introduction, emphasizing that the Simon lecture series will "reaffirm [America's] unique greatness and historic mission." By its own experience, noted the president, Adelphi would show other universities how to "deal with national and global problems in the American way, the William E. Simon way, 
the Columbus way." Simon reiterated that the point of the series was to feature speakers "who exemplify a commitment to the principles which have given this nation the greatest individual freedom ever known to man." Striking was his reference to Diamandopoulos, who had carried out "courageous acts in a tide of antagonism...and outright hostility from some members of the Adelphi Faculty." It was akin to the plight of Christopher Columbus and his legacy, now "under siege" from those with "politically correct agendas," as if the man were "a villain, [a] sea-going Genghis Khan," Simon commented. Now, he added, it is common to "attack everything [Americans] were brought up to revere," and thus Columbus has been covered by a "shadow of cruelty, atrocity, and disease." Simon reminded the audience of Columbus' true greatness: he was a man of "deep faith" whose "entrepreneurial skills" had promoted "a revolution in human thought." Thereafter, America - the United States - had become the model for "a new global culture," "a leader in education," "a nation of doers," all examples of leadership whose renunciation Simon adamantly opposed. In all, Simon combined characteristic positions of neo-conservatives in higher education: an assumption that nefarious powers and principles had prevailed; a reaffirmation of the primacy of Western civilization (including historical notions widely considered superficial); a profession of "faith;" and a strong reiteration of the values of free enterprise. ${ }^{19}$

Afterwards, Adelphi had its share of Olin and Simon lecturers, several of whom were also "Olin scholars" teaching at the university. David Gress, of the Hoover Institution and Adelphi, spoke on "Tocqueville: Prognosis for Democracy and the American Prospect" in 1995, two weeks after another Tocqueville-themed talk by former Dan Quayle assistant Carnes Lord. Ronald Radosh, the former radical historian turned quite conservative, gave an Olin lecture during the same year on "Black Power, White Liberalism, and the Transformation of Democratic Politics." 20

Heavy hitters came in for the William E. Simon Lectures in American Civilization and Values. William F. Buckley addressed the Adelphi community in the fall of 1993 on "Reflections on Current Contentions in America." Provost Igor Webb, apparently referring to the national circuit of Simon lectures, jokingly declared by way of introduction that this was "the lecture series that caused the fall of communism." Buckley spoke at length on individualism and the rights of individuals. At the bottom of America's social problems were illegitimate births, a spur to greater crime, poverty, and joblessness. A "reaffirmation of marriage," he said, would help to reverse that trend. Irving Kristol's lecture a year later on "American Values and the Welfare State" followed similar logic. The new provost, Mark Blitz, a product of the neo-conservative Hudson Institute, introduced the veteran editor. Kristol lamented the decline of individual initiative: he called for the abolition of welfare, urging the poor to work as 
hard as immigrants from Greece, Portugal, and Russia had done. Society badly needed a stable set of values: "The world of today has stolen from us our churches," and consequently "individuals lack the knowledge and guidance to live decent lives."'

Although Simon was the most well connected Adelphi trustee, his many commitments made him the one with the least time to spend on university concerns. Accordingly, he stepped down from active board membership only a year after becoming a trustee. The Adelphi board gave him "honorary" board membership in 1991. His strong impact was felt nevertheless over the next six years, as he visited the campus regularly. But it was through the Olin Foundation that Simon exercised the most influence at Adelphi. ${ }^{22}$

Under William E. Simon, the Olin Foundation commonly allocated grants to universities and programs within them, to hire professors and subsidize research. Thus, the foundation helped establish the John M. Olin Program in Law and Economics at both Cornell and Columbia University Law Schools. Adelphi University became a significant beneficiary as well. From the carly to mid-1990s, the university acquired a group of specially supported Olin Scholars, who remained for a specified period. The coming of the Olin professors, coincided with the burgeoning of Adelphi's core curriculum. Though often re-shaped, the curriculum was originally conceived as a formula to revive classical training as in universities long ago, prior to momentous changes in education and knowledge during the mid and late $20^{\text {th }}$ century. That goal, though in fact never realized, would clearly have caught the attention and support of Simon, producing Olin funds and Olin professors. Olin grants stipulated, and the Adelphi board clearly understood, that such faculty would teach in the core curriculum. ${ }^{23}$

A survey of the Olin professors at Adelphi suggests that a number were tied to influential institutions, in and out of government. Nicholas $X$. Rizopoulos, for example, was Director of Studies for the Council of Foreign Relations from 1989 to 1994: the Council has long been prominent in shaping foreign policy, and was also the recipient of Olin grants. ${ }^{24}$

Further to the right, Carnes Lord also brought substantial foreign policy experience, and a marked Cold War outlook, to his Olin professorship at Adelphi. As a former advisor to Vice-President Dan Quayle and a one-time staffer at the National Security Council, Lord possessed expertise on techniques of psychological warfare, which he discussed and whose perfection he advocated with clear conviction. His experience was primarily in the field of military strategy, gained not so much in the battlefield or the classroom, but at higher altitudes where grand strategies and policies are determined. From the same end of the political spectrum came Olin professor Maurice Cowling, a prominent New Right theorist at Cambridge University. ${ }^{25}$ 
Not quite as established, historian Ronald Radosh taught as an Olin scholar in Adelphi's core curriculum. Given the political stipulations inherent in Olin funding, the foundation's confidence in Radosh was not undeserved: he had moved quite sharply right since his radical beginnings. By the time he was placed on the Adelphi faculty, having been personally recruited as an Olin professor by Diamandopoulos, he had also come to embrace the accumulative ethos proclaimed by William Simon and epitomized by the Adelphi president. To critics of the Adelphi president's lavish lifestyle and compensation, Radosh replied: "I don't know of a college president in the U.S. who doesn't have a...car, a few houses." 26

Historian and German-specialist David Gress also met Olin scholar requirements when he taught at Adelphi: he holds (with some nuances) the contributions of Western civilization to be foremost in world history. Gress enjoyed an affiliation with prestigious foreign policy institutes in Europe and the United States, including the Hoover Institution and the Foreign Policy Research Institute (which accords a dominant role to the United States in world affairs). In his condemnation of Martin Bernal's Black Athena, which describes African influences upon and interactions with ancient Greek civilization, Gress censured the author for his left-wing sympathies and pedigree. ${ }^{27}$

Gress was not the only Olin scholar at Adelphi agitated by radicals. When Tibor Machan spent a Simon-funded year at the Garden City campus, he emphasized in core curriculum debates that Marxism was "extended tribalism" and socialism "a hopeless and muddled system," leaving "individualism" as the "better candidate to solve human problems," certainly superior to "communitarianism." Machan, an Auburn University philosopher, was perhaps the most interesting of the Olin appointees to Adelphi during the Diamandopoulos period. An internationally known promoter of Ayn Rand's philosophy, he raised propositions of self-aggrandizement to the realm of higher thought, an appropriate theorist for Adelphi in the 90s. Widely published and well spoken, Machan had been director of educational programs for the Rand-ist Reason Foundation and editor of its journal. Long associated with libertarian critics of traditional conservatism, he enjoyed affiliation with other foundations promoting Rand's injunction not to demean the wealthy, doubt the successful, or "smear the Profit Motive," but to remember instead that "Americanism and the Free Enterprise System.... are inseparable, like body and soul." Constituting a part of conservatism's libertarian current, such organizations have become known for "their equation of individual freedom with unregulated capitalism." 28

In academia, according to Machan, individualism should be taught as the most important drive and pattern adding strength to societies, wherever they are. Failure to understand this had undermined civilizations. And insofar as 
diverse societies rest upon and deserve an equal place, Machan nevertheless observes that the individualism he considers primary did not originate just anywhere, but rather essentially "in the Western world," giving to that sector a special prominence. ${ }^{29}$

The libertarian view of social understanding and mutual cooperation postulates an "anti-statism" of the type associated with Friedrich Hayek and the journal The Freeman. Machan thus contends that laws prohibiting smoking at work sites and public places infringe upon "individuals' property rights" apparently "protected by the Fifth Amendment." Any limitation, the health dangers notwithstanding, should be up to the individual owner of the location in question: general regulations ordained from above for the "public good" are unconstitutional. Machan supported a similar principle for those who labor, as for those who breathe: there are no rights, beyond being treated with consideration, to which a working person is entitled: benefits must remain the prerogative of the employer to bestow or withhold. ${ }^{30}$

More deeply, Machan (who shared with Gress a tie with the Hoover Institution, and who had taught at West Point shortly before coming to Adelphi ${ }^{31}$ ), felt that the need to own was the most human trait. Not unlike William E. Simon, Machan believed that the media and the schools were accomplices in promoting negative images of corporations, sending Americans "into a business world with their moral sensitivities blocked by exaggerated condemnations of the institution of which they will be part." 32

Varying in profundity and scope, the positions of key Olin appointees to Adelphi tended to coincide, and were matched in turn by influential members of the university's Board of Trustees. A former member evaluated the board under Diamandopoulos as "so packed with ideologues, I think they are more concerned with Peter's value to the right wing community, than a college professor or college president who fights the good fight." Trustees John Silber and William E. Simon were evidently not alone within the board in supporting a narrow emphasis in curriculum, as trustees were unanimous in rejecting changes in the "Western" focus and the "back to the classics" imperative. Although a professor of education challenged the board's power to "decide what knowledge is taught at the University" and a historian wondered if the board would usurp "academic freedom," the board nevertheless endorsed curricular proposals emphasizing "Greek and Roman languages," "Western philosophy and religion," relegating the "non-Western" to courses "taught periodically by adjunct instructors." Given that the focus was to be exemplified in the core curriculum required of all students, and that Olin Scholars figured prominently in the board's conception of that design, the judgement of an Earth Science major was not surprising: "We are force fed rightist viewpoints." 33 
Among Adelphi's trustees, the more vocal and articulate conservatives held persuasive hegemony over the less interested or involved, facilitating easy and consistent agreement. But it should not be supposed that the less ideological among the trustees were puppets. Thus, when she became board chair in 1993, insurance executive Ernesta Procope warned that the educational enterprise at Adelphi operated amidst a societal "breakdown of the institution of the family which has always been the adhesive that has bound our society together," an "erosion in values and in moral and religious beliefs on which our country was founded," an apparent "separation of gays and lesbians as another situation which is interrupting the orderly course of education in America today," and "pressure for 'political correctness' being brought on faculty members and administrators." 34

Trustees like John Silber clearly held great influence in the Adelphi Board of Trustees. During the presidency of Ronald Reagan, philosopher Silber had won appointment to the Bipartisan Commission on Central America headed by Henry Kissinger, which counseled and backed American policy against oppositional movements, and to the Presidential Advisory Board for Radio Broadcasting to Cuba, which encouraged the use of Radio Marti as a foreign policy instrument. As keynoter at Diamandopoulos' inauguration, Silber had lambasted on moral grounds the dissipation of classical education and the emerging doubts within the academic community about courses featuring "Great Books." That even so great a school as Harvard had taken a step toward reconsidering the definition of "core" demonstrated a crisis in the society at large, proof that "we have so lost our way," Silber maintained. On the ethical plane, trustee Silber did not begrudge college administrators financial rewards that might come their way. On the other hand, he strongly opposed faculty unions, as at his own Boston University and at Adelphi. Silber had a record of contentious and censorious relationships with Boston University faculty and staff, having survived a no-confidence vote only through veto by his own board. In the process, Silber had built a reputation as a consistent foe of liberalism. As an Adelphi trustee, Silber considered faculty opponents of the university's board to be "scoundrels," literal foes of "civilization": "That's what we have here - local barbarians coming straight up from within the university." 35

On the Adelphi Board of Trustees in the early to mid-1990s, the Olin Foundation was represented by both executive director James Piereson and president William E. Simon. Editor and cultural critic Hilton Kramer, whose New Criterion received abundant support from the Olin and Scaife foundations, also sat on the board, and became noteworthy as a public exponent of the board's positions in the pages of Rupert Murdoch's New York Post. Indeed, "conservative foundations often are aggressive about having grantees espouse their views," and such men, needing no coercion in any case, were not shy about it. . $^{36}$ 


\section{Rosenberg}

Although serving for a short term, Yale historian Donald Kagan also blended into the board's orientation: he has held Karl Marx responsible for the signal error which "has dominated Western ideas for well over a century," the focus on class. In keeping with board policy, Kagan strongly opposed the dislodging of Western civilization from the center of the academy, an opposition epitomized as well by the conservative National Association of Scholars, to which he, Diamandopoulos, Kramer, and Silber all belonged. Like the bestconnected Adelphi Olin scholars, Kagan had linked his traditional approach to scholarship tightly to political predilection in calling for the United States to maintain the dominant position (especially militarily) in contemporary world affairs, which he associates with the most honorable values of the past, noting with regret that Americans themselves had held particular doubts ever since the Vietnam War. Kagan was no less committed to neo-conservative decision-makers, past and present, than the most active board members. Peter Diamandopoulos, a trustee in his capacity as president, also believed that American leverage, enriched by "good living" at home and enabled by the ability to protect "it against any threat from the outside," was a given component of higher civilization. An allegiance not to conservative ideals in the abstract, but to political, economic, and social power in the neo-conservative mold, the type that has been least conducive to amendment or popular input, seems to have been a hallmark of such trustees. ${ }^{37}$

University administrators thought and acted accordingly. Evidence reveals frequent invocation of rigid hierarchy in academic life, along with support for the concept of an all-powerful leader. Concepts of a core curriculum devoted to "modernity" focused on what university spokesmen felt was the motive force in contemporary society: individualism. World-views taking society or groups as the starting point of analysis were pronounced "pre-modern." The administrative approach assumed that the most important ideas, hinging on individualism, were "Western" in origin and were unencumbered by contradictory and different experiences, even in the "West." As Adelphi's senior vice-president put it: "The only thing I think Western has to mean is that all this stuff came out of the Western tradition, the one ironically, all the people who are powerless certainly want to acquire." Perhaps William F. Buckley placed the prevailing university position most directly when he told the Class of 1995: "We are advanced in basic ways over cultures, that are, yes, less civilized." 38

In establishing the board, administration, foundational support, and visiting professorate on political grounds, Adelphi was lauded by college rankers on the right. Stipulated criteria for high ranking included a Western-based curriculum, featuring traditionally recognized great books and a devotion to some notion of "political incorrectness." William F. Buckley's National Review issued a College Guide which recommended schools with curricula that 
respected "the tradition of the West" and repudiated the lures of "feminism, black studies and affirmative action, gay rights and 'sensitivity rules," which had all made their appearance in the academy "under the banner of DIVERSITY." The Guide accordingly placed Adelphi on its list (while the university put its editor on the faculty, along with the former editor of the New Criterion), praising the way the university's core disseminated great ideas. ${ }^{39}$

Several administrators in the relevant years had strong neo-conservative or Cold War identities. Mark Blitz, provost for a brief time, came from the Olinbacked Hudson Institute to work with Diamandopoulos, for there "are extremely few places run by people like Peter who know what a university should stand for and are doing what's necessary to make it happen. Most colleges have lost their sense of education as a kind of transformation of the soul." Blitz had advised educator and former Reagan/Bush cabinet member William Bennett (one of the foremost neo-conservatives) who charged that the "liberal elite," including academics and "the art community" had wreaked havoc on America's values, denuding college study of "the great works of Western civilization" and producing "a loss of moral and intellectual purpose." Diamandopoulos also employed veteran diplomat Milton Frank, an old friend whose State and Defense department career featured public relations work for America's Vietnam policy and the North American Air Defense Command. Frank had organized Diamandopoulos' inauguration at Adelphi in 1986, at a reputed cost of $\$ 350,000.40$

At those moments when the administration, trustees, and president came under scrutiny - and later under investigation - it was not unusual for their defenders to redbait, an echo of several contemporary Adelphi commencement addresses. Thus, faculty hostility to the university's leadership reminded provost Igor Webb of how the Communist regime had pursued "thought control" in the universities of his native Czechoslovakia. There, as at Adelphi, faculty chiefs had enforced "a strict political correctness mainly through a kind of vicious peer pressure and obligatory conformity. Improper utterance was brutally denigrated." Similarly, it seemed to Olin-funded sociologist Edith Kurzweil that Diamandopoulos's faculty opponents wanted him "to hire only the like-minded." In fact, claimed trustee chair Ernesta Procope patriotically, Diamandopoulos' endeavors benefited "our nation and the western world as well," squaring well with the president's stated aspiration to be "an influence on the larger world." Examining the juxtaposition of articles in the student newspaper, for and against the administration, university spokesman Vince Passaro accused the students of maneuvers found in Communist newspapers: "This is Soviet-style editing, and Soviet-style 'replying,' it seems to me." A student retorted: "It is disingenuous of him to charge this newspaper with 'Soviet-style' editing or other like practices, insofar as The Delphian has no power...to cen- 
sor, harass, bar, ban, fire, persecute or destroy. Neither do the students or the faculty have that power. Clearly, that authority emanates from only one person." Nonetheless, after the state Regents had dismissed the Adelphi board in February 1997, the trustees' attorney Stanley Arkin (who frequently defended firms against charges of malfeasance, questioning the intelligence of victims in the process) denounced the investigation of the board as "reminiscent of the Moscow trials of the 1930's." 41

As a meeting place for ultra-conservatives of national and lesser repute, Adelphi hosted several centennial conferences toward the end of Diamandopoulos' tenure, drawing a number of leading writers and speakers, among them trustees Hilton Kramer, John Silber, and Donald Kagan. Diamandopoulos had originally proposed that the centennial demonstrate the "symbolic connection" between the efforts at Adelphi "and the history of education traceable back to Greece." Fittingly, the Board of Trustees hoped that the meetings would draw national attention to the university's reflections upon the "Values, Aims, and Responsibilities of Western Civilization." Though conference participants included a number outside the realm, the proceedings of the conferences (held under the auspices of the literary journal Partisan Review, edited by Olin Scholar Edith Kurzweil) nevertheless demonstrate the tone set by the most conservative presenters.

Taking its title directly from Diamandopoulos' aforementioned centenary slogan, "Beyond the Twilight of Reason," the March 1996 gathering witnessed biophysicist E.O. Wilson's condemnation of "the increasing disintegration of college and university curricula," the introduction of the by-now familiar John Silber as "our nation's leading college president," and Silber's own denunciation of the attempt to replace Western culture in the curriculum with "the feminist story behind the story, the ethnic interpretation, the multicultural interpretation, or the deconstructivist approach to these issues." So bleak was the academic picture that Hilton Kramer characterized it as being in a dark tunnel. Commentator Stanley Crouch more hopefully opined that the concrete views of the Founding Fathers on such matters as race and gender were of little consequence, as they had transmitted a flexible renewable mechanism to later generations, making "our American story the story of working toward an understanding of universal potential," in contrast to the popular stress on gender and ethnic inequities (evidenced in what Crouch termed the "canonization of Malcolm X"). Noted historian Gertrude Himmelfarb's attacked the "race-class mantra" in higher education: "It is divisive, setting every group against every other; subversive, undermining the common core of knowledge that was at the very heart of the curriculum; and ultimately nihilistic, denying the very idea of truth that was once the aspiration of scholars and students alike, of whatever color, sex, or ethnic and economic background." Indeed, Himmelfarb went on 
to describe the related "social pathology" of the present day breakdown in values: "crime, welfare dependency, illegitimacy, functional illiteracy, drug addiction, alcoholism, and so on," in a session chaired by the not unsympathetic Silber. ${ }^{42}$

A gathering held in November 1996 under the title "Breaking Traditions: Fin de Siecle 1896 and 1996" brought together a similar group of neo-conservatives with relatively non-political speakers, with the former establishing key themes. Diamandopoulos suggested there that the attacks on traditional scholarship and worldviews reflected the transition from "rationalism to subjectivity" in the $20^{\text {th }}$ century, equating his own outlook with reason. Warning of the "upsurge of post-modernism, New Age, and sectarianism," historian Walter Laqueur regretted the elements which had become dominant: "There is a new wave of relativism and nihilism on the ideological level: the campaign against reason, rejection of truth as corresponding to reality, moral philosophy, and so on." But no participant was more articulate than the Olin Scholar Tibor Machan, who invoked Ayn Rand's ideas: the priority of the private sphere and of private property in the definition of freedom on the one hand, and the negative association of contemporary liberals with the sort of community responsibility ethic put forth by Marxism on the other. ${ }^{43}$

The main positions expressed at the Adelphi conferences coincided with the positions of key policymakers and scholars, who had come to identify American supremacy with its ostensibly deep cultural roots in humanity's most respected ideas. The latter had emerged naturally from the evolution of "the West" and of "democracy," which originated in ancient Greece, migrated to Rome, apparently expired for a thousand-year Middle Age, revived under European capitalism, and culminated at last in the United States of America. Antecedents of that outlook emerged at the time of the First World War, including a more pronounced curricular emphasis on the "West."

Cold War-era decision-making (of which neo-conservatives in and out of Adelphi were fond) had made the connection between the status quo in politics and its reflection in higher education and curriculum development, as universities fashioned a richer heritage for the centrality of the "West" and its embodiment in the United States. To some, any alternative to or questioning of that framework crossed the "twilight of reason" over into irrationalism, proof that "the American mind" had succumbed to "subjectivity" as Diamandopoulos put it. A liberal McCarthyism now prevailed, they claimed, wielded by special interest populations (feminists, gays, blacks) whose emotional grievances became the driving force of curricula. The remedy, as Diamandopoulos put it, was "radical reconstruction of all academic offerings." 44

At the dawn of the core curriculum, Diamandopoulos had discouraged making the examination of non-European cultures anything more than ancil- 
lary to the central tenets. "I will not grant you separate courses," was his answer to a group of students who felt that civilizations outside the West belonged in the academic canon. Though some students continued to feel the need to press for an expansion of the curriculum, the Associate Dean for Minority Affairs could still regret by 1993 that their sensitivity to "Eurocentrism" was not taken seriously by his fellow administrators.

University leaders associated black and other minority critics of the president's curriculum with a tendency to harp on archaic wrongs. Indeed, said the president, such students would do right to "forget their minority status and excel." Diamandopolous was proud of his approach to black and other minority students. He remembered that, while dean of faculty at Brandeis University, "My record was brutal with the blacks," but they respected him: "Why did they like me? I always told them, 'I owe you nothing. I didn't have slaves." His Adelphi administration struck some as insensitive. When Adelphi's black firstyear enrollment declined, an administrator urged students to see the bright side, for now the university's freshman class was the "academically strongest ...Adelphi has ever had." 45

Adelphi's leaders were also opposed to unions, particularly to faculty unions. Not unlike trustees and administrators elsewhere, many held not only a professional relationship to the corporate world, but an ideological affinity for free market values. Insofar as they idealized the condition under which businesses operated with a free hand, they viewed university operations in much the same way, giving shorter and shorter shrift to faculty and student voice, with obvious less patience for collective bargaining. Adelphi hired a preeminent national thinker in this regard. Within the huge City University of New York in the early 70 s, Vice Chancellor David Newton had farsightedly proposed the phasing out of full-time faculty and the institution of a "teaching force for CUNY composed largely of adjuncts and therefore inexpensive, expendable, and flexible enough to meet the changing needs of the city economy." Viewing transformation of the labor force as a process, Newton felt that the main question was "no longer whether faculty unionism and collective bargaining are the wave of the future, but rather whether higher education will ride or be engulfed by that wave." As Adelphi's Vice-Provost for Faculty Relations during the Diamandopoulos years, Newton was responsible for dealings with all campus unions, supported or acceded to Diamandopoulos' demands to enforce faculty discipline and compliance, yet exhibited a more nuanced view of collective bargaining in higher education and at Adelphi than did the university's neo-conservatives, who repelled him. Indeed, Adelphi's administrators and trustees (including Kramer and Silber, who shared Newton's New Deal roots) remained unswervingly hostile to faculty unionism, rejecting any semblance of riding a "wave." Their stance drove Newton, who possessed a long record of tough 
negotiations with faculty unions and who opted to endure them when no other choice was possible, to comment in retrospect that "whenever you have characters like Diamandopoulos - and there are more of them than you think unionism is needed." 46

A former organizer for the United Electrical, Radio, and Machine Workers of America, Newton seemed to persuade Diamandopoulos at one point to accept the faculty union. Two years before the clerical workers' strike in 1989, the university and the American Association of University Professors reached a new contract, prompting Diamandopoulos to acknowledge "the established traditions at Adelphi regarding labor relations between the Faculty and the University" in "the full spirit of collegial mutual regard." University trustees endorsed the provisions which "commit all parties involved to uphold collcgiality, enhance the professionalism of the Faculty, and jointly protect and foster the University's educational and fiscal integrity." Hence, they saw no conflict in the coexistence of academic collegiality and collective bargaining at a private university, the Supreme Court's Yeshiva decision notwithstanding. ${ }^{47}$

But the president's anti-union sentiments resurfaced when the clerical workers struck, and never seemed to ebb, particularly in regard to the faculty union. Somewhat hopefully, he told the trustees in 1990: "The faculty has been controlled and directed; they are not running the university." As a columnist noted in 1991, Diamandopoulos regarded the perennial disputes over his leadership "as an evil caused by unions. In particular, he doesn't believe professors should be unionized." The more the critics found fault and inferred malfeasance, the more did the administration and trustees attribute responsibility for the school's problems and negative publicity to the faculty union. The university, charged the trustees, had been "subjected to a well-financed 'corporate campaign' by a small group of dissidents, mainly the directorate of the faculty union, who have long been seeking to gain control of campus policy." Such forces, Diamandopoulos reasoned, aspired to "declare ownership of the university," constituting, in the words of another administrator, a "reactionary clique." 48

Ironically, the corporate ethos within higher education had taken its toll on the security and conditions of faculty in the United States during the Diamandopoulos years. The signal result was the erosion of the full-time work force, as anticipated years before by David Newton. Thus, by the end of the 1990 s, nearly 40 percent of the faculty in the massive State University of New York were part-timers. Across the nation, 43 percent of professors fell into the part-time category. Among full-time faculty, nearly 30 percent worked under non-tenure-track contracts, customarily one year in duration, the prospect of renewal an annual mystery. A detailed study used the term "casualization," (a term traditionally applied to seasonal or irregular labor, as in longshore and tourism) to describe academic work. ${ }^{49}$ 
In response, many faculty chose to organize during the 1980 s and 1990 s, including part-time and full-time teachers at both private and public colleges. While the National Labor Relations Board denied union rights to many faculty applicants after the Yeshiva decision, it gave approval when it found legitimate faculty input so obstructed by trustees and administrators that an employee-employer dichotomy had evolved. The NLRB accepted collective bargaining by graduate students and adjunct faculty at a number of campuses, including New York University, Temple, Yale, and the University of Wisconsin. The NLRB did not classify the full-time professors as managers at Florida Memorial College in 1982, at Bradford College in the same year, or at the University of Great Falls in 1997. The NLRB felt that, despite the operation of shared governance principles on paper, the administrations of these schools totally disregarded faculty participation. To be sure, the NLRB accepted the Yeshiva logic in many other cases, in spite of evidence that corporate-bureaucratic approaches were being broadly introduced into university life and governance, with deleterious impact upon faculty rights, as Justice Brennan had originally observed in his Yeshiva dissent. Yet the course of faculty-university relations was clearly more complex than imagined by neo-conservatives in the Adelphi board..$^{50}$

Nevertheless, Adelphi trustee Donald Kagan, whose labor relations record as Yale dean in the early 1990s were described as "stormy," believed that professors nationally had stonewalled collegiality and curricular innovation. At Adelphi, according to board member Hilton Kramer, "liberals and leftists" had contrived to bring down the high-minded designs of a visionary president and leadership. His colleague John Silber could share Diamandopoulos' frustrations with Adelphi faculty, as Boston University professors had fought him as well, but felt that the Adelphi head was in a tougher position as a result of the greater damage inflicted upon him by the union. So too did a university attorney charge that the critics had used the union as an instrument against the president. Endeavors to remove the president had never been well intentioned, said another, but rather embodied "a campaign to either take over the university or tear it down." Indeed, as the university centennial approached in 1995, Diamandopoulos informed the trustees that "the time has come to induce the faculty to decide collectively whether they are mere employees or true faculty in collegial relations." Accordingly, the Adelphi board assigned several trustees, including the experienced Silber, to a "Shadow Advisory Committee for Labor Relations" in 1995. Soon after, university lawyers petitioned the National Labor Relations Board to decertify the faculty union. Expecting labor difficulties in the fall of 1996 , the university advertised for replacement professors. ${ }^{51}$ 
All in all, there were sound reasons for his supporters to embrace Pcter Diamandopoulos. He had consistently put forth an acceptable platform, to which he added the distinctive elements of his personality and apparent crudition. William E. Simon, whom the president went to great lengths to see at places far removed from Adelphi, expressed well the esteem in which the president was held: "I consider Peter a Renaissance man. He's fighting the conventional wisdom of tenure. He's not tolerating the liberal garbage that spews around. He's hired teachers willing to teach freedom. If he stays for the next ten years, Adelphi will be one of the best institutions around." Long before Diamondopoulos came under the kind of scrutiny necessitating her protection, board chair Ernesta Procope praised him as "visionary, a renaissance man," who employed his "trail-blazing endeavors" to "correct the ills of our society," thus "serving not only our own students, but our nation and the Western world as well." To board member and advertising magnate George Lois, Diamandopoulos was "one of the great men in American education." Like sympathetic people in the board, administration, and among the Olin Scholars, Diamandopoulos took no "nonsense" from anyone. He maintained throughout that his steady perspective, the very intensity and height of his aspirations to raise Adelphi to unprecedented levels, were bound to win him enemies. People with irrevocably lower horizons would be most likely to challenge him, an expectation from which his supporters did not dissent. True, he could be stubborn, said Lois, but it was understandable. "He can be a gigantic pain in the ass. He can't abide fools." And why, aside from the requirements of polite socicty, should fools be abided?

Diamandopoulos insisted that he was "unorthodox and iconoclastic," not least because he claimed to be driven by vision and honesty simultaneously and with "obsessiveness." On that score as well, he expected problems, since most university leaders lacked the strength to make that combination or the ability to see as far. Nonetheless, he once admitted that his "biggest failure would be if I'm just remembered as a person who just created trouble." But life had taught him that "the world is an extremely difficult place to realize any idea and to change anything for the better. Human beings are extremely recalcitrant material. If you are too hard, you threaten them and they will kill you. If you are too soft, they will take over and reduce you to a cipher. If you are neither, they will try to absorb you. But they will not leave you alone." 52

Consequently, his reports to the trustees consistently spoke of current, pending, and anticipated confrontations with newly-empowered lesser lights, apocalyptic speculations unanimously adopted by the sober business people, academics, and scientists who made up the board. Relevantly, then-chair James Byrne, vice-president of Bankers Trust, was moved to warn in 1990: "The status quo is at an end at Adelphi." For as Diamandopoulos reminded the board 
the following year, they were battling "the dominant trends of our times": the lowering of standards and the retreat from higher aspirations. But Adelphi's leaders would not be deterred from the path to "excellence," nor would they stoop to "backtracking or wavering" along the way. "The University is at a crossroads," fighting against "all kinds of odds," intoned the president in early 1993, "but in the end we will prevail." Two months later, he considered his accomplishments to be so "fragile" as to leave him with three stark options: to declare victory, albeit insecure; to quit, then and there; "or to say we must move forward," the statesmanlike course he preferred. As the board's adversaries represented "entrenched interests" and an "old guard" committed to "the security of complacency rather than the uncertainties of innovation," he could not abdicate his "vision," he told the board in 1994, because then "the University would return to the status quo with revenge." What motivated his faculty opponents, he remarked before the state Board of Regents in 1996, was the legacy of the 1960s and 1970s, a desire to "use students in an immoral way to advance their own political and institutional agendas," to which he could not accede. ${ }^{53}$

Diamandopoulos was wont to compare himself to great thinkers of the past, which left his supporters in both the board and the administration unfazed. "Like Socrates, I am always probing," he told an interviewer in 1991: "They killed him. I hope I fare better." He picked up the refrain after his removal in 1997: "But Jesus was betrayed, Socrates was betrayed and Thucydides was sent out to be devoured by wild dogs in Thrace. It happens to anyone, who am I to avoid such a fate?" The Adelphi trustees shared his self-estimate, ultimately considering the investigations of his and their conduct to be a "massive crucifixion," and warned: "The Judas' [sic] responsible for this crucifixion will pay for their betrayal [,] for Adelphi will rise quickly and become the great institution for which Peter Diamandopoulos has had visions of at the year 2000 and beyond." 54

Early on, the Adelphi president had reminded professors that he was the chosen instrument of the Board of Trustees, notwithstanding faculty rights of self-governance. He felt no motivation to invite selected faculty and students to board meetings, insofar as the trustees were already (1989) fed up by the fact that "nine-tenths of their mail" declared "We don't like the President." Years later, Diamandopoulos took pains to spell out the chain of command: "But, keep in mind, an academy is a hierarchical institution, more like a corporation, or as the history of universities suggests, like an ecclesiastical institution, than it is like a democratic microcosm in which different constituencies are 'represented." Faculty, he observed, had no particular right of access to the trustees anyway, since "they are employees of the school... and employee-employer communication was another separate issue." The university was "not a representative government," he insisted: "I'm running a business here." Indeed, 
"within a hierarchical structure of authority...duties, responsibilities, and powers are not commensurate." An ostensible "straight talker," he warned one faculty critic that his opposition was "akin to gross insubordination in the industrial model." He claimed to grasp the motivations of college students better than they did themselves: they in fact "do not know what they need." 55

Such invocations to personal and hierarchical power were not challenged by the board or by most within the administration. Instead, the president's positions were defended as if he were somewhat higher than human. Indeed, stated one administrator, "the strength of Adelphi is exactly vested in the president," the ideal of individualism embodied. Diamandopoulos was "the institution's voice, the institution's authority, the institution's cement," without whom "the institution would unravel fast." Having warned faculty almost from the inception against "unsolicited representations to the board," a point the board took pains to reiterate over the years, the trustees unequivocally supported the personal authority of Diamandopoulos at every turn thereafter, sanctioning "the leader's" philosophy and practices. In fact, stated the president to the board in 1993, "I must be the leader in promoting the University outside. All in all, superintending the academy, telling the students I love them, interpreting the whole thing to the village, and the nation" constituted the responsibilities delegated to him by the trustees. He was convinced of his fulfillment of the second task, later testifying that "I know the students, sir, and I love them" before the state Board of Regents. ${ }^{56}$

The president's grandiosity went unedited into the major administrative pronouncements approved by the board as the 1990 s proceeded. Adelphi's goal, read an Academic Plan, was "transformation of mind," to promote "that path of excellence whose uncommon mark is unity of thought and action." The objectives were to be higher than those of other schools, and would establish Adelphi's national pre-eminence. The university endeavored "to rediscover the lost vision of higher education" and "to give fresh power to the all-but-abandoned idea of education as a preparation, achieved through the discipline of reason, for the quest of truth - about one's self, about one's world." And further, to enable the student to "do what is right, and to know," that is "to transform the novice into a free and responsible person," knowing how "to think, to act, and to achieve." In so doing, stated the university's Centennial Program, Adelphi would challenge the bleak intellectual prospects of a modern age "bereft of transcendent meaning," for "we find ourselves everywhere in the twilight of reason." 57

Diamandopoulos left a strong impression. Commentators long noted that he was "blunt and outspoken" (as were Silber and Simon), evoking a string of lasting images: "provocative," "abrasive," "offensive," "confrontational," "arbitrary." He possessed "a shock of white hair, thick black brows, and hooded 
eyes," facilitating "a spectacular range of expressions," of which the most evident was "impatience, which seems to grip him whenever anyone else is speaking." Listening made him restless. An apparent student of strong military leaders - Patton, Giap, Montgomery (he had in fact chaired the Board of Advisors of the U.S. Command and General Staff College in 1987) - he struck observers as "exceedingly ambitious, flamboyantly autocratic," a "visionary despot," relishing the latter term. ${ }^{58}$

Whatever the occasion, he always spoke at great length. Learnedness and elocution, as if every word held lasting value, erupted in all directions. He improvised esoterically, resorting effortlessly to an apparent galaxy of parallels. The style served to propel the image of an unusually higher intelligence. Olin professor Maurice Cowling, one of Britain's leading neo-conservative historians, praised his "eloquence, vision and ability," but Diamandopoulos tended to antagonize those not indebted to or in agreement with him. Indeed, suggested a student, administrators and faculty members who supported him seemed to have been among the highest paid. The early concern of a quite sympathetic trustee, that the president needed to learn to work "more patiently" with others, was neither heeded, nor formally expressed. A former trustee, who had originally recommended Diamandopoulos' appointment, had come to the conclusion within four years that "[T]his is a dangerous man who functions as a despot in a totalitarian state," one engaged in stacking the board with "his personal choices... who are all beholden to him" (echoing W.E.B. Du Bois' description of a college where "discipline is choking freedom, iron-clad rules, suspicion, tale bearing are almost universal"). Seeing little "vision" in the president, the former board member confessed to being "shocked and chagrined by what has transpired," regarding the hiring of Diamandopoulos as "the single worst example of poor judgment that a number of us have exercised in our professional careers, one that I will always regret." Indeed, as obvious as his energy and aspirations may have been to visitors, many at Adelphi were more likely to doubt that the president had any good intentions. Seven years into the president's term, a correspondent averred that Diamandopoulos "does not have the best interests of the university at heart, that his stated academic goals are not honestly voiced or intended. 59

The evidence demonstrates that Diamandopoulos had great difficulty following agreed-upon methods in university conduct, exploding at meetings of deans and of faculty over the checking of this plan or that vision, employing vivid battle imagery. A former administrator testified that, as the groundswell of opposition to him grew in the fall of 1995 , the president could not contain his rage at a gathering of deans: "He said this is war. He said, 'Guns, machetes, mortars, no prisoners, no Geneva rules.' He said, 'I never lose a battle."' And although the university quickly issued a denial, that deportment (along with 
threats to bring the university down with him) was not uncommon, as confirmed in testimony before the Board of Regents by other leading members of his administration. Of the Adelphi president's frequent invocations of war, Robert Mendelsohn (who did not oppose him) noted: "That's the way he talks." At meetings nearly a year later, Diamandopoulos used similar language, including a litany of weapons to be wielded when "chopping and slashing" those who feared he and the board were steering Adelphi to disaster. He made a point both to deny that catastrophe awaited and to release himself from culpability should it arrive. ${ }^{60}$

A unique personality, there were elements in his make-up that were not exceptional. Though never an ideologue, he expressed the views of the most conservative members of the board, the free market thinktanks and foundations, the more outspoken Olin Scholars, and the currents of rightwing thinking in higher education and national decision-making. That the university, as the Board of Regents inquiry would show, was rapidly deteriorating on Diamandopoulos' watch, seemed to carry no weight with the trustees to whom he was responsible. Rather than putting him in conflict with those supporters whose temperaments were more restrained, his peculiarities were devoted to serving the same political ends, with a sense of ultimate righteousness that many of them in fact advocated in business, government, university life, and the military. In their own worlds, the president's influential backers chafed no less at contrary notions and perceived reversals, and strove as hard against broadly acknowledged norms they could not swallow. To this sort of conservative, the confrontational stance seemed to come more naturally. An example, constituting something of a turning point, was the highly charged speech by William E. Simon at the Adelphi centennial celebration in 1995, in which he called for the abolition of tenure, unnerving many in attendance, including members of the Garden City community. ${ }^{61}$

It seemed to some, for example, that society had developed a bias against great wealth, in conjunction with a tendency to question baser motivations in the corporate world. While William E. Simon was among the most aggressive national defenders of competitive values and the resultant good life, the Diamandopoulos leadership contained others as well, among administrators, Olin Scholars, and trustees.

When the Adelphi board extended salary and benefit arrangements lifting Diamandopoulos to second place in university presidential earnings by 1995 , it precipitated the issues leading to their downfall. On the ethical plane, particularly in light of the condition of the university, the president's remuneration and attendant financial advantages for board members produced the material that would fatally undermine the Diamandopoulos leadership. Nevertheless, as indication of the greater background, the leadership would respond in the terminology of ideology and politics. 
The university's full-time enrollment fell from 3,670 in 1987 to 1,905 in 1996 (and by 16 percent between 1995 and 1996), layoffs and program reductions had been implemented, and the school's budget remained tuition-driven. But the president's income by the mid-90s exceeded that of his peers at much more successful institutions: $\$ 523,626$ in 1994, and some 30 thousand dollars higher the following year in salary and benefits. A good number of extras increased his estimated annual compensation to between 700 and 800 thousand dollars. ${ }^{62}$

Other data exposed a remarkably high rate of attrition - double the national average - among Adelphi faculty. In all, 148 new professors came to Adelphi during the presidency of Diamandopoulos: forty remained by the time of his dismissal. None of those who arrived in September 1985, when Diamandopoulos did, were still employed at Adelphi by 1997. Only seventeen left because they were denied tenure. The period witnessed a steady flow of new faculty from the university, as well as marked administrative turnover. ${ }^{63}$

As revelations became more detailed in 1995 and 1996, Diamandopoulos spoke candidly: the comforts of fine living strongly appealed to him. Educators like him "don't believe we have to suffer. We don't believe we have to be inelegant. We don't believe we have to be chubby and grubby in order to do a good job." He was in a position to do something about it. "I am a businessman and I invest money in stocks and bonds. I invest money buying houses. I invest money buying some art for the university and other things that enhance the elegance of the institution, which I regard as critical." Like many leading higher education figures, he belonged to very exclusive private clubs; but he was virtually alone among them in sending that information to Who's Who in American Education. Committed to the pursuit of elegance, Diamandopoulos stressed: "A president is running a business. I' $m$ selling a vision and a service. I am accountable for anything and everything that is happening." No ceiling could rightfully be placed upon payment for educational services rendered. Similar concepts, particularly with regard and deference to pecuniary values, obtained among the other trustees as well. While never all-embracing, trustee Hilton Kramer's guidelines for selecting honorary doctoral candidates were nonetheless instructive: "Scholars and people of wealth should be considered for academic honors." 64

Needless to say, the president's advocates asserted the justness of his financial rewards as well as the principle that critics should mind their own business. Even before the full details emerged, Olin Scholar Tibor Machan told students to leave the issue of Diamandopoulos' salary alone, for they knew nothing of how the free market determined compensation and were under the delusion that the president was stealing from the university. He felt it best if students "just got down to constructive, creative work, and not bellyache so much 
about other people's wealth. It is quite unbecoming and suggests flaws in one's character." In turn, a correspondent accused Machan of trying to "bully" students by curbing their freedom of speech (and of filling his own lectures "with intellectual rhetoric and nonsense.") But later, putting matters plainly, an administrator put Diamandopoulos' rewards in pecking order context: "The Board of Trustees are the people who employ him; they think he's entitled to this compensation, and whether the faculty or anyone else likes it or not is irrelevant." And further, "[T] hey ought to pay him more, and they're going to, if they're given the opportunity:" The Board of Trustees reaffirmed "the appropriateness of the compensation of the President for his achievements and record as the leader of the remarkable revival of Adelphi during his tenure, and for the purpose of securing his continued commitment to lead the University." 65

Diamandopoulos did not feel that living "down-at-the-heels represents a positive virtue." He invested not only in precious artwork and valuable real estate but in the little things as well. With Adelphi funds, he outfitted a milliondollar condominium purchased by the university (later to be bought by him at a discount) with $\$ 1,800$ worth of bathroom towel racks and soap dishes, a mechanism for melting snow on his terrace, and a hundred thousand dollars worth of furniture. He ate and drank at enormous expense, occasionally verging on a thousand dollars in a meal for himself and a trustee. ${ }^{66}$

Specifics aside, the discrepancy between the status of the president and the condition of the school raised questions in the office of state Attorney General Dennis Vacco, a Republican, who launched an inquiry into Adelphi's financial practices during the 1995-96 centennial year. He subpoenaed the school's financial records to determine whether Diamandopoulos was compensated for expenses having nothing to do with his position. And when it became clear that the trustees were undisturbed by the incongruities, concerned Adelphians organized as the Committee to Save Adelphi. Comprising faculty, students, former administrators, and former trustees, the CSA appealed in April 1996 to the Board of Regents, under the New York State Department of Education, to investigate the Adelphi board. The Regents agreed to hear the case, beginning in the summer. The university first welcomed the news, then requested that the hearings be cancelled, and finally asked that they be held in closed session. But the hearings were to go on as scheduled, open to the public. In the meantime, in view of on-going investigations, the Olin Foundation's William Simon and James Piereson resigned as trustees. ${ }^{67}$

The Board of Regents named three of its members to conduct the proceedings. J. Edward Meyer, a veteran lawyer, prosecutor, and state assemblyman from suburban Westchester County chaired the panel. The highest-ranking participant was Regents Vice-Chancellor Louise P. Matteoni, a former teacher in the New York City public school system who was respected throughout the 
state for her devotion to elementary education: she hailed from Queens. The final member was former Queens College president Saul Cohen, one of the nation's leading geographers: like Meyer, he lived in Westchester. ${ }^{68}$

The hearings opened at the end of July, with Diamandopoulos as the first witness. His testimony ranged widely from the details of his lifestyle to the decisions by the Board of Trustees to increase his salary seven times (and to supply numerous other benefits) since he had begun in 1985. Though he had many times spoken of his expensive tastes, befitting someone of his position and type, he told the Regents panel, "I never asked for a raise." But the trustees evidently had favored his efforts, rewarding him accordingly and giving him much leeway in his personal expense account. (The university had been fined by the Internal Revenue Service, however, for failing to report his salary for a five-year period.) Though Diamandopoulos explained that every salary raise had been properly discussed and approved by the trustees, subpoenaed documents proved that this was not so. Moreover, a good number of subpoenaed materials had either not been delivered or appeared with deletions, to the dissatisfaction of panel chair J. Edward Meyer ${ }^{69}$

The Adelphi leader contended that if the data did not show formal discussion of pay increases by the Board of Trustees, the group had agreed to them nonetheless. At least, changes in compensation would "have been announced by the chairman" at a meeting. Regent Saul Cohen asked the president if the pay of an executive, as in industry, would better be pegged to actual accomplishment. In the face of declining enrollment, underfunding, and continuous conflict, Diamandopoulos testified that his remuneration was totally justified: "I have no negative disposition whatsoever compensating in a dynamic academy [the] faculty [and] administrators to the limits of an institution's solvency." And while acknowledging that he had not come to Adelphi in order to prosper, such a prospect was deserved if the proceeds came "honorably." 70

Appropriately, the Regents panel next heard from the chair of the Adelphi trustecs, Ernesta Procope, head of the E.G. Bowman Company insurance firm. Though unsupported by board records, Procope maintained that Diamandopoulos' compensation was adopted by due procedure and was thoroughly deserved. She recounted the achievements leading to the latter conclusion. He had established "rapport with students," brought the school back from the edge of bankruptcy, renewed the physical plant, and set up a division for honors students. He had set up a core curriculum. When questioned about the school's cutbacks, diminishing donations, and declining enrollment, she attributed them to bad publicity, wholly unwarranted.

She granted that the board was not privy to comparative conditions or accomplishments at other schools, and that assessment of the president's performance had taken place rather informally. When one of the Regents asked, 
[D]o you think his compensation is within the bounds... of a university that is not flush?," she answered strongly in the affirmative. Moreover, she contended, acquiring a fashionable condominium for the president's use in Manhattan, was not uncalled for, but rather tied into the upgrading of Adelphi already in progress under Diamandopoulos. City guests of the university could not be otherwise accommodated and anything less would undermine his position: "We didn't want him to stay in a hotel." Her explanation of a special trustee-established sabbatical fund for the president, which accrued annually at one-sixth of his salary (double the rate for faculty) and which he could claim whenever he chose, elicited a heated response from Regent Cohen: "It really is an abuse of sabbatical purposes." But Procope, who was elected chair in 1993, pointed out that John Silber (the highest paid college president in the country) had advised the other trustees on the manner in which American universities compensated chief executives, so the Adelphi board had followed his knowledgeable recommendations. It helped that Silber was placed on the board's compensation committee. After all, "[T] hose of us on the board are not educators. So whom do we turn to - the educators. We asked Dr. Silber about it." Procope testified: "Being an educator, he would certainly know something about how presidents are compensated, and we can certainly learn from him as to what other universities do." $" 71$

But the head of the Adelphi board's compensation committee, private investor Peter John Goulandris, told the Regents panel that the committee never made a systematic study of the pay and benefits extended to college presidents around the country. Neither did the compensation committee attempt to discover that information. Disinterest in comparative figures also typified the salary deliberations in the board before 1993, according to trustee and former chair James Byrne. The Bankers Trust vice-president told the Regents panel that he found comparative data was "really of very little value" in determining Diamandopoulos' pay: he was more inspired by Diamandopoulos' hard work and greater vision. Byrne and two others conducted their own reviews of the president's performance; not reflected in the minutes, he would try to catch trustees on their way out of board meetings and tell them his recommendation: "They all said it was fine."

That informal undocumented method was confirmed in the testimony of other trustees, such as Leonard Riggio of Barnes \& Noble and Abraham Krasnoff, former president of Pall Corporation, who felt the president deserved all the perks, but conceded that "we were derelict" in failing to abide by necessary process. Peter John Goulandris emphasized that the trustees had relied more heavily on their "best judgement. Yes, there are limits, but we have to judge what the limits are." Goulandris reasoned that "it's hard to find good people," but when found, talented executives should be encouraged by incentives 
to remain. "I certainly think we have a heavy responsibility to spend money wisely. But within that context, all we can do is apply our wisdom."72

Clearly, knowing nothing and having no data were no impediment to the exercise of wisdom in compensation matters. Understandably, the board would have given close attention to the advice of Boston University John Silber, whose counsel was taken seriously on educational matters, of which salary and benefits were evidently considered part and parcel. He seemed to appreciate the political issues involved in Adelphi conflicts, was himself a beneficiary of an even larger compensation, knew what Diamandopoulos meant by "elegance," and could justify the good life philosophically. With equal support for the direction in which the president was steering the school, in light of national debates over curriculum and values, the other trustees would no doubt have endorsed maximizing "the limits" of his pay. Defending Diamandopoulos' purported achievements against apparently baseless attacks by visionless critics, even the trustees without political stake became convinced that the president deserved "every penny" and so testified.

That the relevant decisions were made with no supporting evidence, and with no mention in the Adelphi board minutes, concerned the Regents panel. More disconcerting was the revelation that the trustees had for years eschewed conflict of interest disclosures suggested by the board's auditor. The evidence demonstrated that firms owned or directed by several members, among them advertiser George Lois, had benefited directly by involvement with Adelphi. (In another instance, when the board opted to contract the university's communications system with NYNEX, Adelphi trustee and NYNEX executive Thomas Calabrese had properly not participated in the vote.)

But facts brought before the Regents also revealed that Ernesta Procope had not abstained or absented herself from the board's choice to make her own E.G. Bowman the university's insurance broker. She acknowledged as well that her firm had made a direct sales pitch to win the Adelphi account. Additionally, while Procope contended that the Board of Trustees held full discussions on signing up with E.G. Bowman, there was no indication to that effect in the minutes, suggesting that the point had not come up. Beginning in 1987, Adelphi had paid over $\$ 7$ million in premiums on 122 policies (among them "an executive kidnapping policy with Lloyd's of London"), from which E.G. Bowman earned $\$ 1.2$ million in commissions. But the company had denied substantive, if any, pecuniary benefits from the relationship with the university. ${ }^{73}$

Despite the emergence of the facts, Diamandopoulos supporters charged that the Board of Regents hearings covered up the truth of the many services provided by the president to the university. What the proceedings had revealed, in their view, was not so much the misbehavior of the Adelphi board, but rather the power of a few disgruntled faculty members - the leaders of the local 
AAUP in the first place - to steer the Board of Regents in their chosen direction. A "band of faculty dissidents" had engineered the investigation in order to besmirch the president. In fact, declared a university affidavit, the problems originated with the fact that "Adelphi is one of a small number of private universities in the country which has a unionized faculty," the Yeshiva decision notwithstanding. Indeed, Adelphi's teaching staff "was the first faculty of any private university to unionize," noted a university "White Paper." Adelphi trustees warned other universities of the impact the hearings would have on the future independence of private universities from government interference, for any school's "faculty or its union or any other self-interested party" might decide to initiate a comparable "smear campaign" in order to challenge "the true governing" role of trustee boards. And visiting Olin professor Maurice Cowling blasted the "influence of faculty and union leaders who by and large were radicals of the 1960s or later," who had brought to bear "a considerable increase in the exercise of power by the State of New York." 74

John Silber testified that Diamandopoulos' work at Adelphi was "one of those watershed experiences in higher education," for the Adelphi president had "chosen to stress this central heritage that we have in our universities of what some people refer to in a limited fashion as western culture." Diamandopoulos, insisted Silber, had "tried to direct that institution away from ideologies into that noble pursuit of truth," and as a result had come under the fire of the AAUP, whose witting or unwitting agent the state Board of Regents had become. A former member of the AAUP, Silber remembered better days when the organization had protected "the moral authority of what were proper standards of performance." But ever since "it decided to become a labor union," the AAUP had lost its way, functioning now as "simply an advocacy group for faculty union issues - wages, salaries, working conditions and so forth."75

Were the Board of Regents to remove the Adelphi trustees, Silber testified, "the consequences would be national in import, no less than of earthquake dimension in the State of New York. It would alter the nature of collective bargaining," licensing faculty unions to pressure administrations by "creating a furor in the press, without the requirement of creating and producing evidence in advance...." University leadership would collapse: "I think it would be nothing short of a national calamity and a simple disaster." If professors wanted to form unions, they were free to do so, but they then forfeited any right to participate in shared governance, declared Silber, echoing the Supreme Court decision in National Labor Relations Board v. Yeshiva University. "What do they want? Do they want to be a collegial partner to the administration in the administration of Adelphi or do they want to run Adelphi?" Silber asked. "As long as they want to run Adelphi, they have no right to a union. If they want to be cooperative members of this community and have a union, then they have to 
recognize that they are labor and we are management, and management does have rights, that we will negotiate at the bargaining table." But he would not stand for bargaining "through defamation, through distortion."

Silber seemed unable to contain himself. During a break in the proceedings, he vented his frustrations with Adelphi faculty, off-the-record, to Regents Meyer and Cohen, which led Meyer to openly question Silber's credibility. Later, Meyer told the Boston University president: "You identify with President Diamandopoulos because he's got a faculty that's protesting and you are on a crusade. You want to beat protesting faculty." Silber answered, "I want to beat liars." And he blasted the Board of Regents: "See, I think that the Board of Regents are involved in what is a work project by a union...the attempt is being made to manipulate you and to misguide you with all kinds of things." The Regents had let Adelphi dissidents inundate them with evidence and exhibits, so that the panelists would never understand what had transpired: "The complexities of issues, you have to face, all of which are predicated on a bunch of goddamn lies. This, it seems to me, is truly outrageous." 77

On a similar note, fellow trustee Donald Kagan (admittedly unfamiliar with the Adelphi situation, as he was the board's newest addition), observed more soberly that at universities across the country, shared governance had been undermined by disruptive faculty. He attributed the decline in collaboration to an abiding professorial enthusiasm for 1960 s and 1970 s popular movements, which derisively questioned well-established, classically based, curricula. Synthesizing the various defenses, The New Criterion's Roger Kimball clarified the argument considerably: "In essence," the case "was a labor dispute masquerading as a battle over educational principle." Diamandopoulos had reaped the weeds sown by all the new offensive trends in academia, "especially the intellectually hollow demands for radical multiculturalism and political correctness." 78

The arguments of trustees and their supporters left panelists Cohen, Matteoni, and Meyer unimpressed. When the hearings concluded, they recommended that the Board of Regents remove all the trustees from the Adelphi board, with the exception of Donald Kagan, the most recent appointee. Agreeing, the Board of Regents dismissed the trustees in February 1997. New trustees assumed office. Kagan soon resigned. Diamandopoulos lingered as president, though no longer a trustee, for several days, and was then dismissed by a new board appointed by the Regents.

The Board of Regents had found that the Adelphi board as a whole had neglected both the necessary "fiduciary duty of care" and the "fiduciary duty of loyalty to the corporation," particularly in the scale of conflicts of interest, contrary to law and custom at non-profit institutions. A number of examples were cited in evidence, including the beneficiary relationships enjoyed by 
Procope, Lois, and others. The Regents established that the Adelphi Board of Trustees committed multiple violations of the Not-for-Profit Corporation Law clauses stipulating ways to determine "reasonable compensation." Infringement of the non-profit code had even extended to insuring Diamandopoulos' "personal jewelry and art collection." Trustees neither studied the compensation issue with the school's welfare in mind, nor with systematic attention to what was "reasonable" in higher education. They relied "instead on their own individual experiences as businessmen and women in corporate America." John Silber alone would have possessed information relevant to a more rounded decision, noted the Regents' report, but "he did not consider it comparable, nor did he share it with other members of the [compensation] committee."

Moreover, the state body held that the Adelphi board of trustees had acted in violation of "the principle of shared responsibility." The trustees had undermined and overridden the right of faculty to participate normally in the implicit and explicit process of running the university's educational affairs, even though the board itself had unanimously approved Articles of Governance in 1990. Too often, according to the Regents, the Adelphi board had followed the hierarchical invocations of Silber, Procope, and Diamandopoulos in deriding faculty input. Trustees had even assented to Procope's "vitriolic" description of the anti-Diamandopoulos campaign as a "crucifixion." 79

The record demonstrates that Diamandopoulos' most vocal constituency considered individual pecuniary accumulation a reasonable goal in university leadership. They did not visualize him in the comfort zone befitting an effective professional in the field, to which one might aspire in return for years of service and accomplishment. On the contrary, they could have only considered it "beyond the twilight of reason" to ascertain a point or level at which the siphoning of funds and goods became exorbitant. Evidence shows they felt that it was normal, moral, and the very essence of freedom to be absorbed in property, and irrational to live otherwise. Despite allusions to vision and culture, they operated almost classically through "fantasy, caprice, and whim" on a baser motive, whose "true norm" was "excess and intemperance..." 80

But the Board of Regents found their actions incompatible with both the values of higher education and the requirements of non-profit law. In short, Diamandopoulos' board violated standards of trusteeship in higher education and traditions of shared governance, which, along with collective bargaining agreements, were encoded in the public record.

Although analysis of the campaign to remove Diamandopoulos falls outside of the present article, it is clear that the faculty, having been at odds with Diamandopoulos almost from the start, fought the one-sided and arbitrary decision-making approved by the trustees. Evidence demonstrates that, prior to the 
revelations of corruption, faculty conducted their opposition on the grounds that university leaders were abrogating the recognized and accepted form of governing higher education institutions in the United States. Conflict between Diamandopoulos on the one hand and former trustees who eventually joined the Committee to Save Adelphi on the other, as between the president and former administrators, did not come out into the open until the matter of his dishonestly determined compensation became public news. Contention in this regard seems to have operated on an individual level. While not necessarily crucial to what occurred, resentment against the president by those who had once joined him at the top served to swell the ranks of opponents. At various moments during Diamandopoulos' tenure, students undertook to challenge certain of his decisions and pronouncements: the student newspapers and some student organizations occasionally reflected these disagreements, but the student government generally did not. Nevertheless, several of the open meetings held by the president during his last moments at Adelphi testify to significant student indignation with the way he conducted himself, and the manner in which he regarded them. One may speculate as well that the clerical staff, having won the bitter strike for union recognition in 1989, was not enamored with Diamandopoulos. ${ }^{81}$

The trustees virtually goaded an anti-Diamandopoulos coalition of sorts into existence. The fact remains that the constituency resisting Diamandopoulos with the greatest persistence was the one that was on the premises for the longest period: the faculty. Leaving aside the anti-labor animus characterizing the condemnation by Silber and others of the Adelphi faculty, the fact remains that Adelphi professors had maintained their share in decision-making through normal governance procedures, including tenure, and by organizing a union, far from normal at private institutions: it was in fact unjustifiable according to the Supreme Court. To take such a step was to recognize that shared governance statutes alone could not guarantee the faculty a voice in college affairs under existing circumstances. Under Adelphi's exacerbated conditions, the notion that usurpers of the shared governance process needed only to be reminded of their transgressions in order to restore it could not be sustained. Moreover, as Justice Brennan observed in his Yeshiva dissent, the college scene in general had been harmed by the prevalence of business ethics within it: the "idealized model of collegial decision-making" had disappeared: "the university of today bears little resemblance to the "community of scholars' of yesteryear." ${ }^{12}$ Its chief spokesmen enthusiastically hostile to collegiality, Adelphi came to exemplify the willful attack upon the traditional relationship, in which case the union represented an important element of protection. Under such conditions, the anti-union argument put forth by the trustees found no takers outside their circle. 
Eliciting greater challenge over time on campus, the claims and justifications of Diamandopoulos, the trustees, and their supporters, also played out poorly in the setting of the Regents hearings. The three-person panel could not be pigeonholed as radical or union-dominated. The state Regents body has never purported to be a leavening agent in academic relations. Composed of people of mildly divergent views, the Board of Regents operated in a state with a Republican governor, a Republican Attorney-General, and a Republicandominated Senate. Yet from the latter quarters, the Adelphi trustees and president drew little support: rather they antagonized and insulted conservative state officials. As much as they were found to have defied necessary process as trustees and university officials, so too did they disdain the process of conducting the Regents hearings. In sustaining the glaring aggrandizement of Diamandopoulos, they clashed with conventional belief in the necessity and benefits of hard work and fair play, alienating local clergy and the Republicanoriented village press. They became isolated, even in the ostensibly friendly surroundings of Long Island's fabled Republican culture. Indeed, the Malverne Community Times demanded "Diamandopoulos Must Go!" fully nine months before the Regents panel convened. ${ }^{83}$

Traditionalism in general did not characterize or explain the Diamandopoulos administration, the buttress provided by rightwing thinktanks, or the disregard for agreed-upon procedures. Instead, a more grandiose ultraconservatism suffused the board, the administration, and the president's office. An attorney's assessment of the Diamandopoulos group is apt: "[T]hese people are really extreme." ${ }^{84}$

The Diamandopoulos constituency favored a confrontational style and a rightwing course in diverse realms: foreign policy, curricular issues, faculty relations. Commencement speakers, Olin Scholars, university administrators, guest lecturers, and board members held forth on the menace of Communism, on occasions wholly unrelated to such utterance. Meanwhile, the "West" was to be put back on its curricular pedestal, with or without due process, multiculturalism was to be excluded or limited, collective bargaining to be discarded when the opportunity arose.

Arbitrariness and corruption are not the exclusive province of any ideology. But in the Adelphi case, the brand of rightwing politics upheld by the various elements of university leadership and backing was interwoven with and helped produce scandal. It put a premium on the philosophy of extreme individualism, particularly with respect to achieving "elegance." Trustees in business, Olin professors, and the president himself, phrased self-indulgence in the vocabulary of individual rights and freedom of action, elevating the defiance of law and procedure to a high principle. 


\section{Rosenberg}

Moreover, the president's backers carried greater weight than most within society, as former cabinet members, White House advisors, party leaders, domestic and foreign policy consultants, corporate executives. His supporters were not average Americans with conventional opinions, but rather well-connected people of an intense conservatism, with the will to violate boundaries in their respective realms: and they seem to have been his only followers. They were accustomed to controlling situations. Perhaps, this explains the disregard for actuality and consequences at Adelphi. In "losing oneself in fantasy" one tends to imagine that "one can do what one wishes," that "one's own initiative has been set free," making it appear that "everything is easy." ${ }^{55}$ However influential and consistent his support, Diamandopoulos and the board proceeded in such a way as to guarantee that their base never grew. Beyond declarations of intent and proclamations of success, they did not succeed in imposing their "vision" upon Adelphi.

${ }^{1}$ Daniel Rosenberg thanks the following for insightful criticisms of various drafts of this article: Les Baltimore, Nora Bonosky, Dominic Cavallo, Cathy Cleaver, Graham Everett, Rudy Fichtenbaum, Marty Haas, Gayle Insler, Wil Milberg, and Jesse Rosenberg

${ }^{2}$ Board of Regents of the University of the State of New York, Report to the Honorable Members of the Board of Regents, re the Committee to Save Adelphi et. al., Petitioners, against Peter Diamandopoulos et. al. Respondents, February 5, 1997.

${ }^{3}$ Thorstein Veblen, The Theory of the Leisure Class (New York: 1953 [1899]).

${ }^{4}$ Elisabet Van Nostrand, Maureen Fan, and Roni Rubin, "A Message to LI's Grads," Newsday, May 21, 1990; Craig Gordon and Estelle Lander, "Graduates Told: Back Your Beliefs," Newsday, May 18, 1992; Robert Fresco, "A Seasonal 10,000 Degrees," Newsday, May 22, 1995; Jack Sirica, "The Educated Elite," Newsday, May 20, 1996.

5 Sara Diamond, Roads to Dominion: Right-Wing Movements and Political Power in the United States (New York: 1995), 198-199; Peter Steinfels, The Neoconservatives: The Men Who Are Changing America's Politics (New York: 1979), 29-32, 64-65, 52.

6 John Silber, "Procedure or Dogma: The Core of Liberalism," The New Criterion, Vol. 17, No. 9 (May 1999); Hilton Kramer and Roger Kimball, ed. The Betrayal of Liberalism: How the Disciples of Freedom and Equality Helped Foster the Illiberal Politics of Coercion and Control (Chicago: 1999); Arthur C. Danto, “A Dozen Years of Solitude: Hilton Kramer," Grand Street, Vol. 5, No. 3 (Spring 1986), 221; Gary Dorrien, The Neoconservative Mind: Politics, Culture, and the War of Ideology (Philadelphia: 1993), 17, 10-13; Jeet Heer, "The Unbearable Dourness of Being (Conservative)," Gravitas, Vol. 3, No. 3 (Autumn 1996), 44.

${ }^{7}$ Richard Panchyk, "Former Treasury Secretary Named to Board" The Delphian, October 11, 1989; Vincent Melomo and Richard Panchyk, "Silber Joins Board of Trustees," The Delphian, September 20, 1989.

${ }^{8}$ Brian O'Sullivan and Vincent Melomo, "Faculty Questions President," The Delphian, February 22, 1989; "Strike Becomes a Seminar," The Delphian, February 22, 1989; Vincent Melomo, "Students Question President," The Delphian, February 22, 1989. 
${ }^{9}$ Brian O'Sullivan, "Strike Concludes," The Delphian, March 8, 1989; Brian O'Sullivan, "Faculty Calls for Dismissal of the President," The Delphian, March 8, 1989; Brian O'Sullivan, "Byrne Rejects Faculty, S.P.A. Resolutions," The Delphian, March 15, 1989; Brian O'Sullivan, "Trustees Support President," The Delphian, April 8, 1989; "A Question of Dignity," The Delphian, April 26, 1989; Vincent Melomo, “Board Responds to Faculty," The Delphian, May 10, 1989.

${ }^{9}$ Vincent Melomo, "More Appointments, More Controversy," The Delphian, September 6, 1989.

11 Adelphi University, Presidential Inauguration Addresses: The Inauguration of Peter Diamandopoulos as the Seventh President of the University, April 18, 1986, 18-22, Adelphiana Miscellany, Presidents, Diamandopoulos, P., Inauguration folder, Swirbul Library, Adelphi University; Board of Regents of the University of the State of New York, Hearings in Re: Adelphi, transcripts, John Silber, August 26, 1996, 1921-1922, Committee to Save Adelphi (CSA) Archives, Adelphi University; U.S. Supreme Court, $N L R B$ v. Yeshiva University, 444 U.S. 672, 695-705 (1980).

${ }^{12}$ Panchyk, "Former Treasury Secretary Named to Board," The Delphian, October 11, 1989

${ }^{13}$ Department of the Treasury, The Learning Vault, Biographical Sketch of William E. Simon, http://www.treas.gov/opc/opc0068.html (Retrieved May 25, 1999); Stevenson, "William E. Simon, Ex-Treasury Secretary, Dead at 72," New York Times, June 4, 2000.

14 "Giving Away a Personal Treasury," The Chronicle of Philanthropy; William E. Simon Foundation, Inc., Home Page, http://www.wesimonfoundation.org/wesf.nsf/html media/body/_index.html (Retrieved June 19, 2000); F. R. Duplantier, "Capitalists Should Crow, Not Cower," America's Future, January 12, 1997, http://americasfiture.net/1997/jan97/97-1)1/2a.html (Retrieved June 3, 1999).

${ }^{15}$ Quoted in Eric Alterman, "The Troves of Academe," The Nation, June 24, 1996.

16 People for the American Way, Buying a Movement: Right Wing Foundations in American Politics, http://www.globalpolicy.org/finance/docs/buymvmnt.html (Retrieved January 5, 2000); Ira Chinoy and Robert Kaiser, "Decades of Contributions to Conservatism: The Right's Funding Father," Washington Post, May 2, 1999; "Scaife Foundation Grants for 1998," http://www:politicalamazon.com/scaifefoundations.html (Retrieved July 14, 2000); House Democratic Policy Committee, "Downsizing the American Dream," A Staff Report of the House Democratic Policy Committee, 1996, http://www.house.gov/democrats/research/downsize.html (Retrieved January 5, 2000).

17 Van Nostrand, Fan, and Rabin, "A Message to Ll's Grads," Newsday, May 21, 1990; Eric Alterman, "The 'Right' Books and Big Ideas," The Nation, November 22, 1999; John M. Olin Foundation, Inc., Schedule of Grants, 1997:H, http://www.jmoforg/grants/1997h.html (Retrieved August 25, 1999); Emily Eakin, "The Oracle at Adelphi," New York Magazine, October 16, 1995; John M. Olin Foundation, Inc., Schedule of Grants, 1996:M, http://www. jmof.org/grants/1996m.html (Retrieved May 25, 1999); John M. Olin Foundation, Inc., Schedule of Grants, 1997:N, http://www.jmof.org/grants/1997n.html (Retrieved May 25, 1999); John M. Olin Foundation, Inc., Schedule of Grants, 1996:C, http://www.jmof.org/grants/1996c.html (Retrieved May 25, 1999); John M. Olin Foundation, Inc., Schedule of Grants, 1996:A, http://www.jmoforg/grants/1996a.html (Retrieved May 25, 1999); Eugene Genovese, "To the Members of the Historical Society: Organization Report," The Historical Society, January 15, 


\section{Rosenberg}

1999; American Academy for Liberal Education, The Academy's Education Standards, http://www.aale.org/edstand.html (Retrieved June 21, 2000); Denise K. Magner, "A Clash on One Campus Shows Evolution of a Fledging Accrediting Group," The Chronicle of Higher Education, December 11, 1998; J. David Hoeveler, Jr., Watch on the Right: Conservative Intellectuals in the Reagan Era, Madison, 1991, 121.

${ }^{18}$ Manhattan Institute for Policy and Research, Past Events at the Manhattan Institute, May 1998April 1999.

19 "The William E. Simon Public Affairs Lectures, 1988-Present," summary description, Gerald R. Ford Foundation, http://www.lbjlib.utexa.edu/ford/library/faintro/grrfoun.1.html (Retrieved June 7, 2000); "William E. Simon Inaugurates New Lecture Series," The Delphian, October 14, 1992.

20 "Notice: The Olin Lectures," The Delphian, March 1, 1995; "The Olin Lectures," The Delphian, March 15, 1995; Fletcher School of Law and Diplomacy, Fletcher Faculty, "Carnes Lord," http://www:tufis.edu/fletcher/faculty/lord.html (Retrieved May 24, 1999); "Historian Ronald Radosh to Lecture February 13," The Delphian, February 8, 1995.

21 Suzy Edwards, "William F. Buckley Lectures on American Civilization and Values," The Delphian, October 6, 1993; "Irving Kristol Lectures on American Values and the Welfare State," The Delphian, October 26, 1994.

22 Minutes of the Board of Trustees, September 26, 1990, Board of Regents, Hearings, Exhibit P48; Board of Trustees Membership Analysis, 1995, Hearings, Exhibit P-271.

23 John M. Olin Foundation, Inc., Schedule of Grants, 1996:C, http://www.jmof: org/grants/1996c.html. (Retrieved May 25, 1999); John M. Olin Foundation, Inc,, Schedule of Grants, 1996:A, http://www.jmof.org/grants/l996a.html (Retrieved May 25, 1999); Minutes of the Board of Trustees, March 2, 1994, Hearings, Exhibit P-145.

${ }^{24}$ Council on Foreign Relations, 1998 Annual Report: Historical Roster of Directors and Officers, 1998, http://www:foreignrelations.org/public/ar98/histrost.html (Retrieved May 25, 1999); G. William Domhoff, The Higher Circles, The Governing Class in America (New York: 1970), 111 155; John M. Olin Foundation, Inc., Schedule of Grants, 1996:C, http://www.jmof. org/grants/1996c.html. (Retrieved May 25, 1999).

25 Fletcher School of Law and Diplomacy, Fletcher Faculty, "Carnes Lord," http://www.tufts.du/fletcher/faculty/lord.html (Retrieved May 24, 1999); Carnes Lord, "The Psychological Dimension in National Strategy," in Lord and Frank R. Barnett, eds., Political Warfare and Psychological Operations, Washington D.C., xiv, 13-37; John Mullan and Giles Foden, "Inside Story," The Guardian (Manchester), September 10, 1999.

${ }^{26}$ Alterman, "The Troves of Academe;" John B. Judis, "TRB From Washington: The Heretic," The New Republic, June 17, 1996; Scott Sherman, "The Radosh File," Lingua Franca, Vol. 9, No. 7 (October 1999), http://www.linguafranca.com/0010/radosh.html (Retrieved August 11, 2000); Jack Sirica, "Adelphi Faculty: President Must Go, Newsday, October 6, 1995.

27 David Gress, From Plato to NATO: The Idea of the West and Its Opponents (New York: 1998); see also Ethics and Public Policy Center, "From Plato to NATO: A Conversation with David Gress," Center Conversations, May 1999, No. 1; "Notice: The Olin Lectures," The Delphian, March 1, 1995; Foreign Policy Research Institute, A Catalyst for Ideas, "Mission Statement," http://www:fpri.org/Internet/index.html (Retrieved June 27, 2000); David Gress, "The Case Against 
Martin Bernal," The New Criterion, Vol. 8, No. 4 (December 1989), http://www.newcriterion. com/archive/08/dec89/gress.html (Retrieved June 27, 2000)

${ }^{28}$ Luis Fernandez, "Core Curriculum Keynote Lecture: Tibor Machan," The Delphian, March 23, 1994; The Radical Academy, "A Short Biography of Tibor R. Machan," http://radicalacademy.com/machanbio.html (Retrieved May 24, 1999); David Harriman, ed., Journals of Ayn Rand (New York: 1997), 352-354; Tibor Machan, "Libertarianism: A Warning," The Libertarian Forum, Vol. 11I, No. 2 (February 1971); Chinoy and Kaiser, "Decades of Contributions to Conservatism," Washington Post, May 2, 1999; Eric Foner, The Story of American Freedom (New York: 1998), 309.

29 Tibor R. Machan, “America's Founding Principles and Multiculturalism," (Retrieved July 7, 2000).

${ }^{30}$ Foner, 308; Tibor R. Machan, “Coping with Smoking," The Freeman, April 1994, (Retrieved May 24, 1999); Tibor R. Machan, Private Rights and Public Illusions (New Brunswick: 1995), 180-182.

31 Hoover Institution, "Tibor Machan," http://www-hoover.stanford.edu/BIOS/machan.html (Retrieved July 7, 2000).

32 Albert Mingardi, "Philosopher Tibor Machan," Laissez Faire City Times, http://wuw:zolatimes.com/V2.21/tmachan.html (Retrieved May 24, 1999); Tibor R. Machan, "What is Morally Right with Insider Trading," http://genius.ucsd.edu/ john/p/libuniv_dir/Machan_dir/ Machan.InsTrad Retrieved July 7, 2000); Tibor R. Machan, "What's All the Fuss About Money," http://genius.ucsd.edu/ john/p/libuniv_dir/Machan_dir/Machan.Money (Retrieved July 7, 2000); Tibor R. Machan, "The Malady of Business Bashing," http://genius.ucsd.edu/ john/ p/libuniv_dir/Machan_dir/Machan.BusiBash (Retrieved July 7, 2000); Tibor R. Machan, Capitalism and Individualism, New York, 1990, 144

33 Jonathan Giovanni, "Interview with Randall P. McIntyre, Part II," The Delphian, April 17, 1996; Carrie Gerkey, "Trustee, Student, and Faculty Involvement an Issue in Core Debate," The Delphian, February 23, 1994; Kathleen Slavin, "Combination of Departments, Faculty Changes, and Western Emphasis Among the Objectives of Proposed 'Academic Plan," The Delphian, March 23, 1994; David Ruppel, "Letter to the Editor," The Delphian, November 3, 1993.

${ }^{34}$ Minutes of the Board of Trustees, September 22, 1993, Hearings, Exhibit P-217.

35 Adelphi University, Presidential Inauguration, April 18, 1986, 8, Adelphiana Misceliany, Presidents, Diamandopoulos, P., Inauguration folder, Swirbul Library, Adelphi University; Jack Sirica, "The Defender-Silber: Diamandopoulos earned pay amid 'Psychic Abuse," Newsday, August 27, 1996; Bruce Lambert, "Salary and Benefits of Adelphi's Embattled President Defended by his Mentor," New York Times, August 27, 1996; Bruce Lambert, "Views Differ on Whether Adelphi's Trustees Should Go," New York Times, August 28, 1996; Jack Sirica, "Silber: Charges Based on Lies," Newsday, August 28, 1996; John Silber, "Procedure or Dogma: The Core of Liberalism," The New Criterion, Vol. 17, No. 2 (May 1999), http://www:newcriterion. com/archive/17.may99/silber.html (Retrieved June 8, 1999); Silber, quoted in Stephen Z. Goldberg, "Letter to the Editor," The Delphian, January 31, 1996. Silber's opposition to faculty and staff unions was noted when he joined the Adelphi board: Melomo and Panchyk, "Silber Joins Board of Trustees," The Delphian, September 20, 1989. See also the detailed account by veteran Boston 


\section{Rosenberg}

University professor Howard Zinn in You Can't be Neutral on a Moving Train, Boston, 1994, 183 -

196.

${ }^{36}$ Eakin, "The Oracle at Adeiphi," New York Magazine, October 16, 1995; Chinoy and Kaiser, "Decades of Contributions to Conservatism," Washington Post, May 2, 1999; Hoeveler, Jr., 121; Mark Fiore, "12 Conservative Foundations Shift Agenda for Policy Research, Report Says," The Chronicle of Higher Education, July 11, 1997.

37 "Kagan Survives Adelphi U's Trustee Purge," Yale Daily News, February 12, 1997; Jack Sirica, "Adelphi Trustee Blames Trends," Newsday, October 19, 1996; Frederic Smiler, "History's Largest Lessons: An Interview with Donald Kagan," American Heritage, Vol. 48, No. 1 (February-March 1997), 59-67; Hearings, transcripts, Donald Kagan, October 18, 1996, 6007, 6061; National Association of Scholars, Is the Curriculum Biased?, November 11, 1995; Donald Kagan, "Intangible Interests and U.S. Foreign Policy," Commentary, April 1997, http://www.cs. texas.edu/users/vl/kagan.html (Retrieved May 24, 1999). The History and Classics departments at Yale - Kagan's departments - were Olin Foundation beneficiaries: John M. Olin Foundation, Inc., Schedule of Grants, 1996:Y, http://www.jmof.org/grants/1996y.htm/ (Retrieved July 14, 2000). Like Tibor Machan, Kagan has also appeared in the Ayn Rand orbit of publications (commonly associated with fairly explicit rightwing viewpoints), albeit on baseball: Kagan, "Joe DiMaggio: Baseball's Aristocrat," Navigator, Vol. 2, No. 9 (May 1999), http://ios.org/ (Retrieved May 24, 1999). Diamandopoulos' remarks are in Harliaos H. Daskalothanassis, "Diamandopoulos on His Ordeal at Adelphi U: I Would Not Quit," The National Herald, December 12-13, 1998.

38 Memorandum from Elliot Pruzan, Associate Provost, to Carl Buxbaum, Chair, Faculty Senate Academic Affairs Committee, April 10, 1996. Subject: A New Core Curriculum Proposal; Eakin, "The Oracle at Adelphi," New York Magazine, October 16, 1995; Courtney Leatherman, "A President Under Fire," The Chronicle of Higher Education, November 3, 1995; Doreen Carvajal, "President's Pay Rankles Some at Adelphi," New York Times, September 30, 1995; John M. Goshko, "School's President Ignites Dispute; Adelphi U. Faculty and Students Rebel Against Lavish Perks and Policy," Washington Post, November 6, 1996; Fresco, "A Seasonal 10,000 Degrees," Newsday, May 22, 1995.

${ }^{39}$ The Radical Academy, Education Directory, http://wwwradicalacademy.com/educationdir.html (Retrieved May 27, 1999); Stephen Goode, "10 Best Colleges," Insight on the News, September 7, 1998; Charles J. Sykes and Brad Minor, The National Review College Guide, New York, 1993, 10, 13, 14, 16, 31 -34; Eakin, "The Oracle at Adelphi," New York Magazine, October 16, 1995.

40 Eakin, "The Oracle at Adelphi," New York Magazine, October 16, 1995; William J. Bennett, The De-Valuing of America: The Fight for Our Culture (New York: 1992), 14, 242, 28, 30, 156, 159 , 173-174; Lawrence Van Gelder, "Military Man Helping Give New Marching Orders at Adelphi, New York Times, October 19, 1996; “Ambassador Milton Frank, 1919-1993," The Delphian, January 27, 1993; Adelphi University, Presidential Inauguration, April 18, 1986, 21, Adelphiana Miscellany, Presidents, Diamandopoulos, P., Inauguration folder, Swirbul Library, Adelphi University; Patrick Kelly, "Letter to the Editor," The Delphian, October 25, 1995.

41 Igor Webb, "Letter to the Editor," The Delphian, October 4, 1995; Edith Kurzweil, "Letter to the Editor," The Delphian, February 7, 1996; Minutes of the Board of Trustees, September 2, 1993, Hearings, Exhibit P-217; Minutes of the Board of Trustees, September 28, 1994, Hearings, Exhibit 
211; Vincent Passaro, "Letter to the Editor," The Delphian, October 25, 1995; Diane Schaefer, "Letter to the Editor," The Delphian, November 1, 1995; Stanley S. Arkin and Jeffrey M. Kaplan, "Business Crime: Criminalizing Sales Practice Violations," International Commerical Litigation, July-August 1997; Bruce Lambert, "Court Order Halts Ouster at Adelphi U.," New York Times, February 12, 1997. For his part, Diamandopoulos suspected that the prestigious journal, Labor History, was a Marxist organ, though the journal is well known for the wide scope of its articles and viewpoints. Interview with David Newton, Vice-Provost for Faculty Relations, January 5 , 1998.

42 Minutes of the Board of Trustees, June 22, 1994, Hearings, Exhibit P-142; Minutes of the Board of Trustees, December 7, 1994, Hearings, Exhibit P-210; Symposium, "Beyond the Twilight of Reason: Rethinking the Western Tradition," Partisan Review, Vol. LXIII, No. 3 (Summer 1996), 381-384; 427; 391-395, 397, 403.

43 "Breaking Traditions: Fin de Siecle 1896 and 1996," Partisan Review, Vol. LIV, No. 2 (Spring 1997), 212, 249, 309-323, 332.

44 Peter Novick, That Noble Dream: The "Objectivity Question" and the American Historical Profession (Cambridge: 1988), 311-319; Gary B. Nash, Charlotte Crabtree, and Ross E. Dunn, History on Trial: Culture Wars and the Teaching of the Past (New York: 1997, 45-51; Lawrence W Levine, The Opening of the American Mind: Canons, Culture, and History (Boston: 1996), 54-64; Bennett, 202; Alan Charles Kors and Harvey A. Silvergate, The Shadow University: The Betrayal of Liberty on America's Campuses (New York: 1998); Minutes of the Board of Trustees, May 1 , 1991, Hearings, Exhibit P-320.

45 "Rally Against Racism," The Delphian, March 3, 1989; Barbara Tokarska, "Adelphi Community Looks at Racism," The Delphian, November 1, 1989; Raymond A. Davis, "Letter to the Editor," The Delphian, October 20, 1993; Giovanni and Shah, "President Diamandopoulos Speaks on Education, the Media, Program Cuts, and the Core Curriculum," The Delphian, February 28, 1996; Marilyn Goldstein, "2 Problem Schools, 2 Problem-Solvers: Diamandopoulos of Adelphi," Newsday, June 6, 1986; Shabnam Shah, "Students Attend Open Forum in Record Numbers," The Delphian, February 14, 1996.

${ }^{46}$ Karen W. Arenson, "David Newton, 76, Open Admissions Leader," New York Times, January 14, 1999; Newt Davidson (Newton) to Governor Nelson Rockefeller, Confidential Memo, "The BHEPSC Contract and Long-Range Planning for CUNY," September 12, 1973; David Newton, unpublished MSS, circa 1973, in author's possession; David Newton, "Faculty Attitudes and Collective Bargaining," presentation at a conference, 1970s, in author's possession; Peter Diamandopoulos to The University, "Restoration of the Faculty Senate Budget," October 3, 1989, Adelphiana Miscellany, Presidents, Diamandopoulos, P. folder, Swirbul Library, Adelphi University; Interview with Newton, January 5, 1998.

${ }^{47}$ Peter Diamandopoulos, Letter to the Adelphi Faculty, September 1987, in author's possession.

${ }^{48}$ Minutes of the Board of Trustees, June 20, 1990; Hearings, Exhibit P-24; Agovino, , "A Modern Day Socrates: Adelphi's Head Plots New Course," Crain's New York Business, March 18, 1991; Bruce Lambert, "New York Regents Oust 18 Trustees From Adelphi U.," New York Times, February 11, 1997; Daskalothanassis, "Diamandopoulos on His Ordeal at Adelphi U: 1 Would Not Quit," The National Herald, December 12-13, 1998; Igor Webb, "Should Adelphi's president Go? No, he turned school around," Newsday, August 25, 1996. 


\section{Rosenberg}

${ }^{49}$ Erika Rosenberg, "Unions Cite Colleges' Use of Part-Time Teachers," Albany Times-Union, October 30, 2001; Nick Bromell, "Summa Cum Avaritia," Harper's Magazine, February 2002, 76; Coalition of Graduate Employee Unions, "Casual Nation," 1999, 1, 2, 4.

50 "Two Unions Compete for N.Y.U. Adjunct Professors," New York Times, March 21, 2002; Ernst Benjamin, "Faculty and Management Rights in Higher Education Collective Bargaining: A Faculty Perspective," Presentation at the $25^{\text {th }}$ Annual Meeting of the Center for the Study of Collective Bargaining in Higher Education and the Profession on April 14, 1997; Florida Memorial College: 263 NLRB 1248; Bradford College: 262 NLRB 565; University of Great Falls: 325 NLRB 83; Scott Smallwood, "NLRB Rules Against Faculty Union at Sage Colleges," The Chronicle of Higher Education, August 17, 2001.

${ }^{51}$ Sirica, "Adelphi Trustee Blames Trends," Newsday, October 19, 1996; Hilton Kramer, "A Phony Issue at Adelphi," New York Post, October 3, 1995; Lambert, "Salary and Benefits of Adelphi's Embattled President Defended by his Mentor," New York Times, August 27, 1996; Bruce Lambert, "Lawyers See a Plot to Sow Controversy at Adelphi," New York Times, September 7, 1996; Jack Sirica, "Adelphi Lawyer Criticizes Critic," Newsday, September 7, 1996; Jack Sirica, "Contentious $101^{\text {st }}$ for Adelphi? Unsettled Atmosphere amid Debate on President," Newsday, August 27, 1996; "Adelphi U. Moves to Decertify Faculty Union," The Chronicle of Higher Education, December 1, 1995; Minutes of the Board of Trustees, March 8, 1995, Hearings, Exhibit P-209; David Newton, Vice Provost for Faculty Relations, Memo to Faculty, Adminstrators, and Staff, Collective Bargaining Negotiations between the Faculty Union and the University, May 24, 1996.

52 See the arrangements to hear Simon's address at the U.S. Air Force Academy, noted in Peter Diamandopoulos, Appointment Calendar, November 13, 1994, Hearings, Exhibit R-28A; Eakin, "The Oracle at Adelphi," New York Magazine, October 16, 1995; see Procope's comments in Minutes of the Board of Trustees, September 22, 1993, Hearings, Exhibit P-217; Bruce Lambert, "Creator of Adelphi's Ads Assails President's Critics," New York Times, August 30, 1996; Curtis Rist, Ron Arias, Amalia Duarte, "For its President, Little Adelphi U. is a Place of Higher Earning," People, November 13, 1995; Carvajal, "President's Pay Rankles Some at Adelphi," New York Times, September 30, 1995; Goldstein, "2 Problem Schools, 2 Problem-Solvers: Diamandopoulos of Adelphi," Newsday, June 6, 1986; Eric Schmitt, "President Revives Adelphi, But at a Price, New York Times, February 18, 1989; Daskalothanassis, "Diamandopoulos on His Ordeal at Adelphi U: I Would Not Quit," The National Herald, December 12-13, 1998.

53 Minutes of the Board of Trustees, March 7, 1990, Hearings, Exhibit P-318; Minutes of the Board of Trustees, May 1, 1991, Hearings, Exhibit P-320; Minutes of the Board of Trustees, March 3, 1993, Hearings, Exhibit P-213; Minutes of the Board of Trustees, May 5, 1993, Hearings, Exhibit P-25; Minutes of the Board of Trustees, September 28, 1994, Hearings, Exhibit P-211; Hearings, transcripts, Peter Diamandopoulos, August 2, 1996, 714.

54 Theresa Agovino, "A Modern Day Socrates: Adelphi's Head Plots New Course," Crain's New York Business, March 18, 1991; Daskalothanassis, "Diamandopoulos on His Ordeal at Adelphi U: I Would Not Quit," The National Herald, December 12-13, 1998; Minutes of the Board of Trustees, December 6, 1995, Hearings, Exhibit P-206.

55 Vincent Melomo, "Diamandopoulos Discusses State of University," The Delphian, October 22, 1989; "President Diamandopoulos' Response to Issues of the Forum," The Delphian, April 17, 
Twilight of Reason

1996; Jonathan Giovanni and Shabnam Shah, "President Diamandopoulos Speaks on Education, the Media, Program Cuts, and the Core Curriculum," The Delphian, February 28, 1996; Memo to the Faculty from Peter Diamandopoulos, President, Subject: Resolution of the "Omnibus Grievance," September 15, 1992; Peter Diamandopoulos to Joseph Ruocco, September 20, 1995 , in author's possession, courtesy of Joseph Ruocco; Shabnam Shah, "Diamandopoulos Speaks to Students," The Delphian, April 3, 1996.

56 Bruce Lambert, "Provost Says Adelphi Needs More, Not Less, Authority," New York Times, September 18, 1996; Melomo, "Board Responds to Faculty," The Delphian, May 10, 1989, Resolution of the Board of Trustees, June 28, 1995, Hearings, Exhibit P-205; Minutes of the Board of Trustees, May 5, 1993, Hearings, Exhibit P-25; Hearings, transcripts, Peter Diamandopoulos, August 2, 1996, 714.

${ }^{57}$ Adelphi University Planning Committee, Adelphi University Academic Plan 1991-1996, Special Collections, Adelphiana Collection, Swirbul Library, Adelphi University; Adelphi University, Periodic Review Report, June 1, 1993, Special Collections, Adelphiana Collection, Swirbul Library, Adelphi University; Centennial Program, quoted in Gunther Geiss and Joseph Ruocco, "Letter to the Editor," The Delphian, October 12, 1995.

58 Carvajal, "President's Pay Rankles Some at Adelphi," New York Times, September 30, 1995; Goldstein, "2 Problem Schools, 2 Problem-Solvers: Diamandopoulos of Adelphi," Newsday, June 6, 1986; Who's Who in American Education, ${ }^{\text {th }}$ Edition, 1996-1997, New Providence (N.J.), 1995, 207; Eakin, "The Oracle at Adelphi," New York Magazine, October 16, 1995.

59 John Mullan and Giles Foden, "Inside Story: Peterhouse Blues," The Guardian (Manchester), September 10, 1999; Maurice Cowling, "Peterhouse on Long Island," The Spectator, April 14, 1997; Diane Schaefer, "Letter to the Editor," The Delphian, October 11, 1995; George C. Andreas to James T. Byrne, Jr., June 28, 1988, Hearings, Exhibit P-8; Susan Brady Svitlik, "Nadel Blasts Adelphi's President," Long Island Business News, July 31, 1989; W.E.B. Du Bois, The Education of Black People: Ten Critiques, 1906-1960, New York, 1973, 45; Lee Morgan, "Letter to the Editor," The Delphian, March 25, 1992.

${ }^{60}$ Bruce Lambert, "Adelphi Chief Vowed War, Ex-Dean Says," New York Times, September 10, 1996; Hearings, transcripts, Jeffrey Kane, November 30, 1996, 7866-7868; Hearings, transcripts, Robert Mendelsohn, September 7, 1996, 5830-5831; Author's notes, Faculty-Administrative meetings, May 15, 1996 and May 22, 1996.

${ }^{61}$ Kurzweil, "How to Save Adelphi University from its Saviours," The Delphian, February 7, 1996; Devin Thornburgh, "Open Letter to Dr. Kurzweil," The Delphian, February 14, 1996; Igor Webb, "Letter to the Editor," The Delphian, October 4, 1995; Interview with the Reverend Jim Adelman, Garden City Community Church, October 10, 1995.

62 Bruce Lambert, “Adelphi's Trustees Ignored Auditor's Advice," New York Times, September 1, 1996; "Regents Have a Job Cut Out for them at Adelphi," Editorial, Newsday, August 9, 1996; Carvajal, "President's Pay Rankles Some at Adelphi," New York Times, September 30, 1995.

${ }^{63}$ Sax, Astin, et. al., The American College Teacher: National Norms for the 1995-96 Survey for the 1995-96 Survey or the 1995-96 HERI Faculty Survey, Los Angeles, 1996; "Faculty Departures (retirements and terminations), new hires, and length of service by rank," tables supplied by Adelphi office of the American Association of University Professors to the Adelphi University 


\section{Rosenberg}

Middle States Sub-Committee on Faculty and Curriculum, January 1998. Administrative turnover is noted in Board of Regents, Report, 45-46.

64 Carvajal, "President's Pay Rankles Some at Adelphi," New York Times, September 30, 1995; Bruce Lambert, "Official Asks if President of Adelphi Should Stay," New York Times, August 3, 1996; Who's Who in American Education, 207; Jack Sirica, "Adelphi Chief: End the Strife," Newsday, August 3, 1996; Minutes of the Board of Trustees, December 2, 1992, Hearings, Exhibit P-2 14.

65 Tibor Machan, "Letter to the Editor," The Delphian, October 19, 1994; "Letter to the Editor," The Delphian, November 2, 1994; Goshko, "School President Ignites Dispute; Adelphi U. Faculty and Students Rebel Against Lavish Perks and Policy," Washington Post, November 6, 1996; Bruce Lambert, "Weighing College President's Annual Worth to Adelphi," New York Times, November 30 , 1996; Resolution of the Board of Trustees, October 19, 1995, in author's possession.

${ }^{66}$ Bruce Lambert, "Examining Adelphi President's Perks, From a Mercedes to a Million-Dollar Condo," New York Times, August 12, 1996; Furniture Purchased by Adelphi for Apartment at 422 E. $72^{\text {nd }}$ Street, NYC, Hearings, Exhibit P-272.

67 Doreen Carvajal, "Adelphi Issues Criticisms of State Case," New York Times, February 2, 1996; Jordan Rau, "Adelphi on Defensive: Seeks to Block Probe on Lavish Spending," Newsday, May 16, 1996; John T. McQuiston, “Adelphi U. Group Asks Regents to Remove Trustees," New York Times, April 26, 1996; Jack Sirica and Jordan Rau, "Regents' Test," Newsday, June 12, 1996; "Adelphi Can't Have it Both Ways," Editorial, Long Island News and Ow'l, July 4, 1996; Bruce Lambert, "Adelphi President Testifies on His Rising Income," New York Times, July 31, 1996; Stipulation of Dismissal of William Simon from the Board of Trustees, Regents Case Files, June 17, 1996, CSA Archives; Thornburgh, "Open Letter to Dr. Kurzweil," The Delphian, February 14, 1996.

68 "J.Edward Meyer," http.//wwu:regents.nysed.gov:9260/meyerhtml (Retrieved August 7, 2000); New York State United Teachers, "Retirement of a Champion for Children," http://www.nysut. org/ra98/news/Friday/retirementhtml (Retrieved August 7, 2000); "Saul B. Cohen," http://www.regents.nysed.gov:9260/cohen.html (Retrieved August 7, 2000).

${ }^{69}$ Lambert, "Adelphi President Testifies on His Rising Income," New York Times, July 31, 1996; Sirica, “Adelphi's Chief Takes Stand in State Hearings," Newsday, August 3, 1996.

70 Lambert, "Adelphi President Testifies on His Rising Income," New York Times, July 31, 1996; Sirica, “Adelphi Chief: End the Strife," Newsday, August 3, 1996.

71 Bruce Lambert, "Official Asks if President of Adelphi Should Stay," New York Times, August 3 , 1996; Bruce Lambert, "N.Y. Panel Queries Head of Board of Adelphi U.," New York Times, August 7, 1996; Jack Sirica, "Diamandopoulos" Perks Defended," Newsday, August 7, 1996; Lambert, “Examining Adelphi President's Perks, From a Mercedes to a Million-Dollar Condo," New York Times, August 12, 1996.

72 Lambert, "Adelphi Trustees Ignored Auditor's Advice," New York Times, September 1, 1996; Jack Sirica, "Worth the Salary," Newsday, September 25, 1996; Bill Bleyer, "Adelphi Hearings Focus on Salary," Newsday, November 15, 1996; Bruce Lambert, "Adelphi Panel Estimates Severance Payout," New York Times, October 23, 1996; Jack Sirica, "Adelphi Trustee Explains Perks," Newsday, August 31, 1996. 
73 Lambert, “Adelphi Trustees Ignored Auditor's Advice," New York Times, September 1, 1996; Jack Sirica, “"Oprah' Was Over Before it Begin," Newsday, August 30, 1996; Lambert, "N.Y. Panel Queries Head of Board of Adelphi U.," New York Times, August 7, 1996; "Regents Have a Job Cut Out for them at Adelphi," Editorial, Newsday, August 9, 1996; Bruce Lambert, "Chairwoman of Adelphi's Board is Accused of Using Her Double Role to Advantage," New York Times, September 24, 1996.

74 John Procope, "The Bowman-Procope Story: Running Blacks Out of Business, a Cottage Industry for The New York Times," The New York Amsterdam News, September 28, 1996; Affidavit of Igor Webb, Attorney General Case Files, CSA Archives, March 15, 1996, 4; Adelphi University, White Paper on the Implications, Background and History of the Current Assertions by the Charities Bureau of the New York State Department of Law (Attorney General) of Jurisdiction Over Private Colleges and Universities, January 31, 1996, 6; Adelphi and Beyond: A Statement by the Adelphi University Board of Trustees, December 16, 1996, 7; Cowling, "Peterhouse on Long Island," The Spectator, April 14, 1997.

${ }^{75}$ Hearings, transcripts, John Silber, August 26, 1996, 1815-1817, 1844-1846.

${ }^{76}$ Hearings, transcripts, John Silber, August 27, 1996, 1876-1877, 1961-1962. See also NLRB v. Yeshiva University, 444 U.S. 672 (1980).

${ }^{77}$ Hearings, transcripts, John Silber, August 27, 1996, 1758, 1996-1997, 2012-2014.

${ }^{78}$ Hearings, transcripts, Donald Kagan, October 18, 1996, 5973-5978, 6062; Roger Kimball, "The Third Degree," National Review, March 10, 1997.

${ }^{79}$ Board of Regents, Report, 14-16, 33-42, 10, 18-19.

${ }^{80}$ Karl Marx, The Economic and Philosophic Manuscripts of 1844, New York, 1964, 147-148.

${ }^{81}$ Shah, "Students Attend Open Forum in Record Numbers," The Delphian, February 14, 1996.

82444 U.S. $701-704$.

${ }^{83}$ Interview with the Reverend Jim Adelman, Garden City Community Church, October 10, 1995; "Diamandopoulos Must Go," Editorial, Malverne Community Times, October 19, 1995. See also “Adelphi Can't Have it Both Ways," Editorial, Long Island News and Owl (Rockville Centre), July 4, 1996; "Adelphi Probably Needs a Clean Sweep," Editorial, Long Island News and Owl, August 22, 1996; Peter Kohler, "Showdown at Adelphi," Cablevision Editorials, February 18, 1997.

${ }^{84}$ Sirica, "Adelphi Trustees Campaign, Warn Other Schools of "Slippery Slope," Newsday, September 23, 1996.

${ }^{85}$ Antonio Gramsci, "On Dreaming with One's Eyes Open and Losing Oneself in Fantasy," Passato e Presente, Turin, 1974, 6, translated by Jesse Rosenberg. 